\title{
Criteria to discriminate between different models of thrust ramping in gravity-driven fold and thrust systems
}

\author{
G.I. Alsop ${ }^{1}$, R. Weinberger ${ }^{2,3}$, S. Marco ${ }^{4}$, T. Levi ${ }^{2}$. \\ 1) Department of Geology and Geophysics, School of Geosciences, \\ University of Aberdeen, Aberdeen, UK. (e-mail: ian.alsop@abdn.ac.uk) \\ 2) Geological survey of Israel, Jerusalem, Israel. \\ 3) Department of Earth and Environmental Sciences, Ben Gurion University of the Negev, Beer Sheva, Israel. \\ 4) Department of Geophysics, Tel Aviv University, Israel.
}

\begin{abstract}
Although most models of thrusting assume that the hangingwall is actively displaced up the thrust ramp while the footwall remains passive, it has been suggested that this could be an oversimplification and the footwall may also deform. Despite this, there are relatively few detailed investigations of thrusts where the footwall is deformed, perhaps reflecting issues with space and accommodation if the footwall actively moves downwards to deeper levels. Furthermore, such studies assume that the thrust is deeply buried otherwise the hangingwall is more likely to rise and simply uplift the surface. Using examples from gravity-driven fold and thrust systems developed in unlithified late Pleistocene sediments around the Dead Sea Basin, we investigate pristine fold and thrust geometries unaffected by later compaction and deformation to establish two end-member models of overthrust and underthrust ramp development. During overthrusting, the hangingwall is uplifted and marker beds remain at or above regional elevation, whereas the footwall of underthrust ramps is depressed and marker beds are deflected below regional. The greatest displacement generally develops low down overthrust ramps and decreases upwards, whereas larger displacements form high up underthrust ramps and reduce downwards. The reduction in displacement in overthrust ramps is marked by decreasing dips, whereas displacement increases with decreasing dips up underthrust ramps. Fault propagation folding creates hangingwall antiforms above overthrust ramps, whereas footwall synforms develop below underthrust ramps. The effect of this folding is that hangingwall sequences and cut-offs are relatively thinned (stretch $<1$ ) in overthrust ramps, while footwall sequences and cut-offs are thinned in underthrust ramps (stretch $>1$ ). Not all ramps follow these end-member geometries and mixed 'wedge' ramps also develop in which the hangingwall and footwall to the ramp are both deformed to varying degrees. Underthrust ramps are generally developed where failure initiates in competent units higher up the deforming sequence, and then propagates downwards towards underlying potential detachments. Downward propagation is accommodated by footwall synforms and weak beds that absorb deformation by differential vertical compaction resulting in up to $50 \%$ thinning in some cases. A consequence of underthrusting is that the crests of hangingwall structures tend to remain at the same elevation and are therefore unable to build significant topography or bathymetry on the sediment-water interface thereby rendering critical taper models of less relevance. Significant vertical compaction may facilitate expulsion of fluids that drive further deformation and may also complicate the use of area balancing techniques during restoration of thrust systems.
\end{abstract}

Key Words: Overthrust, Underthrust. Thrust ramp, Fault-related fold, Dead Sea 


\section{Introduction}

Thrust systems are generally composed of a series of bedding-parallel 'flats' where displacement is accommodated along relatively weak units, together with steeper 'ramps' where displacement is transferred across generally more competent units to create a 'staircase trajectory' (e.g. see discussions in Knipe, 1985; Cooper and Trayner, 1986; Ramsay and Huber, 1987, p.522; Butler, 1987, p.619). If ramps are joined by an underlying detachment termed a 'floor' thrust and an overlying upper detachment termed a 'roof' thrust' then a duplex is created (e.g. Boyer and Elliot, 1982; Butler, 1987, p.620; McClay 1992; Fossen, 2016, p.359). Thrust displacement may create fault-related folds, including fault-bend folds where layers are bent around adjacent ramp and flat geometries, and fault-propagation folds (FPF) that form at the tip-line of thrusts to accommodate variable deformation in the wall rock (e.g. Suppe and Medwedeff, 1984, 1990; Chapman and Williams, 1984; Ramsay and Huber, 1987, p.558; McNaught and Mitra, 1993; Ferrill et al., 2016). In such cases, it is generally assumed, and implicit in many illustrations that it is the hangingwall to the thrust that has moved and absorbed most, if not all, the associated deformation (e.g. see discussion in Strayer and Hudleston, 1997). Indeed, Ramsay and Huber (1987, p.522) note that in the models of Suppe (1983), 'the footwall is completely inert and remains undeformed'. However, Ramsay and Huber (1987, p.524) and Ramsay (1992, p. 191) note that while classic models of fault-related folding only generate folds in the hangingwall of the fault, examination of natural examples reveals folds also form in the footwall. It has been suggested that folding may form in the footwall of thrust ramps due to the creation of new thrusts lower down in the footwall, or by the development of a zone of simple shear on both sides of the thrust that creates underlying footwall synforms, or by thrusts initiating after (and thereby cutting) earlier buckle folds (Ramsay and Huber, 1987, p.525).

Although outcrop examples of the deformed hangingwall and footwall to thrusts have been provided by a number of authors including Cloos, (1961, 1964), Eisenstadt and De Paor, (1987), Ramsay (1992), Martinez-Torres et al., (1994), Berlenbach, (1995), Strayer and Hudleston, (1997), Cawood and Bond, (2020), no such structures have so far been reported from soft-sediment deformation marking gravity-driven fold and thrust systems (FATS) (Alsop et al. 2021). This may reflect the assumption that for footwall deformation to occur, significant overburden is required and that the thrust is deeply buried, otherwise the hangingwall is more likely to move and simply uplift the surface. (see discussion in Ramsay, 1992, p.193). We here present the first case study of footwall deformation created during gravity-driven fold and thrusting of unlithified sediments very close (within a few metres) of the sediment surface.

Working on shallow FATS has the advantage that sediments remain largely uncompacted and retain original thickness variations and angles of dip that provide pristine relationships for the analysis of a variety of different ramp geometries. This study has allowed us to establish a range of criteria and diagnostic parameters that enable different types of thrust ramps to be more clearly distinguished and defined. Our research aims to address a number of questions linked to the development of different types of thrust ramps in gravity-driven FATS. These questions include:

a). What 'end-member' thrust ramp models are applicable to gravity-driven FATS?

\section{b) How do displacement-distance patterns vary in different thrust ramp models?}


c) How is thrust ramp displacement accommodated?

d) How can different thrust ramp models be distinguished?

e) What controls the different thrust ramp models?

f) What are the consequences of different thrust ramp models?

We first outline a general classification of different types of thrust ramps before providing a geological background to the study area.

\section{Models of thrust ramp development}

The relationships between thrust ramps and folds are most clearly observed where displacement along thrusts remains relatively minor $(<10 \mathrm{~m})$ meaning that patterns and geometries associated with the initiation of ramping are still preserved and not overprinted by larger offsets associated with continuing deformation. We consider folding that is generated by the thrusting process (i.e. fault-related folds), rather than earlier buckle folds that are subsequently cut by later thrusts (i.e. break-thrust folds) (see discussion in Morley, 1994; Alsop et al., 2021). We also stress that in the scenarios described below, thrust ramps do not necessarily propagate directly from an underlying basal detachment. The concept of regional is defined as 'the elevation of a particular stratigraphic unit or datum surface where it is not involved in the thrust-related structures' (McClay, 1992, p.422, his fig. 16) and is critical when considering relative and absolute motions on faults and folds (e.g. Butler et al., 2020). In most thrusts and contractional faults, the 'hangingwall is elevated above regional and there is shortening of the datum plane' (McClay 1992, p.422). Building on the fault-related fold models of Ramsay (1992, p.192), we divide potential thrust ramp relationships into three types.

\subsection{Model 1 - Overthrust ramps}

Overthrusts may be defined as where "an overlying thrust sheet has been displaced relative to an unmoved footwall" (Ramsay and Huber 1987, p.521) and represents the classic thrust ramp model as illustrated by Chapman and Williams (1984) (Fig. 1a, b). Model 1 is marked by local uplift of the actively deforming hangingwall markers above their regional elevations (Re) (Fig. 1a-d). Bedding planes of the hangingwall are parallel to the underlying ramp, apart from where hangingwall cut-offs develop, while the bedding planes of the footwall maintain regional dips. The passive footwall remains relatively undeformed (e.g. Suppe, 1983; McClay, 1992) and thereby maintains regional elevations (Fig. 1c, d).

\subsection{Model 2 - Underthrust ramps}

Underthrusts may be defined as where "the footwall has moved beneath the hangingwall" (Ramsay and Huber 1987, p.521) and envisages a passive hangingwall with an actively deforming and folded footwall in a situation that is the reverse to Model 1 (Ramsay 1992, p.193) (Fig. 1e,f). Bedding planes of the footwall are parallel to the underlying ramp, apart from where footwall cut-offs develop, while the bedding planes of the hangingwall maintain regional dips (e.g. Berlenbach, 1995, p.36). Markers in the deformed footwall are deflected downwards below regional elevation, while the passive hangingwall maintains 'regional' elevations (Fig. 1e, f). 


\subsection{Model 3-Mixed wedge ramps}

Mixed wedge ramps refers to cases where the footwall and hangingwall to thrust ramps undergo broadly equivalent amounts of deformation (e.g. Ramsay, 1992; Woodward, 1992, p.204; Strayer and Hudleston, 1997) to create lenses or 'wedges' of thickened strata on either side of a ramp (Cloos, 1961, 1964). Model 3 involves active deformation of both the footwall and hangingwall and results in a mirror image down-bending of the footwall and elevation of the hangingwall markers relative to their respective regional levels (Fig. 1g, h) (e.g. Chapman and Williams, 1983, their fig. 2a, p.122; Ramsay 1992, p. 197). Bedding planes in both the footwall and hangingwall are rotated to dip parallel to the thrust ramp (Fig. 1g). However, we stress that it is also entirely possible in some cases for competent beds in central areas next to sites of fault nucleation to remain at regional dips, with folds only developing towards the upper and lower fault tips where displacement has been arrested. This overall scenario has been referred to as the 'Kimmeridge model' (e.g. Berlenbach, 1995, p.35) after where it was described in detail by Ramsay (1992, p. 199) (Fig. 1h). We prefer to use the term 'mixed wedge' model to reflect the mixture of deformation in both the hangingwall and footwall as originally described by Cloos $(1961,1964)$ and reflected in Models 1 and 2 respectively.

\section{Geological Setting}

\subsection{Regional geology}

The Dead Sea Basin is a continental depression bounded by two major, left-stepping, sinistral fault strands that generate numerous earthquakes and collectively form the Dead Sea Fault (DSF) (Fig. 2a, b) (e.g. Marco et al. 1996, 2003; Ken-Tor et al. 2001; Migowski et al. 2004; Begin et al. 2005; Levi et al., 2006a, b; Weinberger et al., 2016). The DSF, which initiated in the early Miocene (Nuriel et al., 2017) and continues to be active today, was also operating during deposition of the Lisan Formation in the Late Pleistocene (70-14 Ka) (e.g. Bartov et al. 1980; Garfunkel 1981; Haase-Schramm et al. 2004). The present study focuses on structures formed within the Lisan Formation that comprises detrital-rich layers washed into the lake during flood events, intercalated with mm-scale aragonite laminae that were precipitated from hypersaline waters during the summer (Begin et al. 1974; Ben-Dor et al. 2019). Detrital units consist of quartz and calcite grains with minor feldspar and clays (illite-smectite) that display $\sim 8-10 \mu \mathrm{m}$ (silt) grain sizes, while thicker $(>10 \mathrm{~cm})$ detrital-rich units are very fine $(60-70 \mu \mathrm{m})$ sands (Haliva-Cohen et al., 2012). Isotopic dating of the Lisan Formation combined with counting of aragonite-detrital varve couplets indicates that rates of deposition were generally $\sim 1 \mathrm{~mm}$ per year (Prasad et al., 2009). Despite the well-defined and finely laminated beds of the Lisan Formation being deposited on very gentle $\left(<1^{\circ}\right)$ regional slopes, subsequent earthquakes along the bounding fault systems led to slope failure and creation of gravity-driven fold and thrust systems (FATS) within mass transport deposits (MTDs) that moved downslope towards the basin depocenter (Marco et al., 1996; Agnon et al., 2006; Lu et al., 2017; Levi et al., 2018).

\subsection{Patterns of regional MTD movement}


Mass transport deposits (MTDs) are associated with slope failure in both marine and lacustrine settings and are increasingly recognised across a range of scales from both seismic analysis (e.g. Armandita et al., 2015; Scarselli et al., 2016; Steventon et al., 2019; Nugraha et al., 2020; Sammartini et al., 2021) and outcrop-based studies (e.g. Morley et al., 2011; Sharman et al., 2015; Sobiesiak et al., 2016, 2017, 2018; Jablonska et al., 2018; Cardona et al., 2020; Alsop and Weinberger, 2020).

Within the Lisan Formation, MTD's contain FATS that collectively define a radial pattern of downslope-directed movement towards the centre of the Dead Sea Basin (Alsop et al., 2020a, b) (Fig. 2b). In the NW part of the basin, MTD's move towards the ESE, in the central part of the basin around Miflat and Masada they translate eastwards, whereas in the southern portion of the basin at Peratzim they are directed towards the NE (Alsop et al., 2020a) (Fig. 2b). To the east of the Dead Sea in Jordan, El-Isa and Mustafa (1986) have shown slumping in the Lisan Formation is directed towards the west, thereby confirming the overall downslope movement of sediment towards the basin centre. Locally, transverse structures such as the NESW trending Amazyahu Fault may influence movement patterns and generate southerly-directed MTDs in the southern part of the basin, although these are not considered widespread (Weinberger et al. 2017, Alsop et al. 2018a; 2020c) (Fig. 2b). Movement directions of MTDs have been further substantiated by analysis of Anisotropy of Magnetic Susceptibility (AMS) fabrics from within the FATS exposed along the western shore of the Dead Sea (Weinberger et al. 2017). This collective input of MTDs from around the basin margins results in greater thicknesses of sediment in the depocenter, where drilling has shown the Lisan Formation to be three times thicker than its (now) exposed marginal equivalent (Lu et al., 2017, 2021; Kagan et al., 2018).

The present study focuses on well-exposed FATS that are clearly-defined by the finely laminated aragonite and detrital-rich layers of the Lisan Formation along the western margins of the basin (Fig. 2b). Bedding-parallel detachments that form adjacent to the thrust ramps in the FATS are extremely planar and traceable for up to tens of metres and the limits of individual outcrops (e.g. Alsop et al., 2017a, b). Detachments do not result in brecciation or break-up of the juxtaposed beds and form surfaces that, apart from the adjacent ramps and associated folds, are largely indiscernible in the local stratigraphy. In some instances, detachments are marked by thin $(<30 \mathrm{~mm})$ horizons of mixed aragonite and detrital material that forms a buff-coloured gouge along the detachment (Weinberger et al. 2016; Alsop et al. 2018, p.109). Locally, the mixed gouge forms injected 'fingers' that penetrate into the overlying stratigraphy and suggest high pore fluid pressures were attained along the detachment (Alsop et al., 2018, p.109, their fig 7j).

Our data was collected from the vertical walls of modern wadis that incise across the deformed MTD horizons within the Lisan Formation. The canyon walls form approximately 2D sections with subtle relief, although the unlithified nature of the sediments allows easy excavation where 3D observations are required for structural analysis. The orientation of cross sections for investigation was carefully chosen to lie parallel to the fault slip direction representing the approximate movement direction of the FATs (see Alsop et al. 2017a, b, 2018 for further details). The section views are therefore representative of the true thickness of beds and true displacement across thrusts, rather than any apparent thicknesses or estimates of 
displacement resulting from oblique views. Measurements and observations were made either directly in the field or from scaled photographs taken normal to the section wall.

Previous analysis of fold and thrust geometries has shown that detrital-rich layers preserve Class 1B parallel, buckle fold styles, whereas aragonite-rich beds are marked by Class 2 similar folds (classification following Ramsay, 1967), indicating that detrital-rich beds where generally more competent at the time of folding and thrusting (e.g. Alsop et al. 2017a, b, 2020d). We highlight specific examples of a range of thrust ramp geometries from outcrops at Miflat $\left[\mathrm{N} 31^{\circ}: 21.42^{\prime \prime} \mathrm{E} 35^{\circ}: 22.49^{\prime \prime}\right]$ and Masada $\left[\mathrm{N} 31^{\circ}: 20.02^{\prime \prime} \mathrm{E} 35^{\circ}: 21.24^{\prime \prime}\right]$ in the central DSB, together with localities at Peratzim $\left[\mathrm{N} 31^{\circ}: 04.56^{\prime \prime}\right.$ E35 $\left.: 21.02^{\prime \prime}\right]$ and Wadi Zin [N30 $: 53.41^{\prime \prime}$ E3 $\left.5^{\circ}: 17.26^{\prime \prime}\right]$ from further south in the DSB (Fig. 2b). All of these sites are located $\sim 1-2 \mathrm{~km}$ east of the Dead Sea western border fault zone that forms the basin margin (Fig. 2b). The Lisan Formation at these marginal locations was deposited in water depths of $<100 \mathrm{~m}$ for much of the time between 70 and $28 \mathrm{Ka}$, apart from a brief interval from 26-24 Ka when water depth temporarily increased up to 200m (Bartov et al. 2002; 2003). Erosive surfaces cutting folds and thrusts at the top of MTD's (e.g. Alsop et al., 2019) indicates that deformation occurred close to the sediment surface. The lack of significant overburden $(<5 \mathrm{~m})$ above the Lisan Formation, coupled with the relatively shallow water column means that the thrust ramp structures we now analyse have retained largely pristine geometries.

\section{Parameters and data used to define and distinguish different thrust ramp models}

\subsection{Uplift or depression of markers relative to 'regional' elevations}

As noted previously, the 'regional' of a stratigraphic unit is the elevation of that particular marker horizon where it is unaffected by later faulting (e.g. McClay, 1992) or folding (e.g. Butler et al., 2020). The concept of regional allows the absolute uplift or depression of a marker to be determined, and hence in the case of thrust faults, it helps determine whether it is the hangingwall or footwall to the fault that has been raised or lowered respectively (Figs. 1a-h, 3a).

Our elevation data is normalised against the maximum recorded uplift or depression of a marker layer across the thrust (measured from its regional), and each example can therefore be directly compared. We stress that this is only an approximate comparison as the true regional may lie beyond the limits of local exposure, while components of lateral compaction leading to layer thickening may go largely unrecognised (i.e. all marker beds may have been deformed to some extent). However, given these caveats, our data generally provide coherent and consistent patterns across a range of settings and ramp types. In our examples of Model 1 overthrust ramps (Fig. 4a-i), marker beds in footwalls to ramps maintain, or are only slightly depressed, compared to their regionals $(\mathrm{Re})$, whereas the hangingwall markers are raised with the largest uplift recorded at greater distances from the upper reference point (R) (Fig. 3a, b). In our examples of Model 2 underthrust ramps (Figs. 5, 6), marker beds in the hangingwall to ramps are only slightly elevated compared to their regionals, whereas the footwall markers are significantly lowered with the largest depression recorded closer to the upper reference point (Figs. 3c, 5a, b, 6a-d, 6f-h). In our examples of Model 3 mixed wedge ramps (Fig. 7), marker beds in footwalls are moderately depressed compared to their regionals, while hangingwall markers are raised, 
with the larger uplifts recorded further from the upper reference point (Figs. 3d. 7a, b, e, f). The general relationships between elevation of regionals and movement across thrust ramps in the three models is summarised in Table $1 \mathrm{a}, \mathrm{b}$.

\subsection{Displacement-distance plots}

Displacement-distance (D-D) plots compare the amount of displacement of a marker across a fault with the hangingwall distance of that marker from a fixed reference point (' $R$ ') (e.g. Muraoka and Kamata, 1983; Williams and Chapman, 1983; Chapman and Williams, 1984; see review by Hughes and Shaw, 2014) (Fig. 3a). Different marker beds are measured along the length of the fault to create a D-D plot for that particular fault (e.g. Fig. 4a-d). Our displacement and distance data are presented in both measured ( $\mathrm{mm}$ ) and normalised formats to aid comparison between different structures. Normalised displacement plots involve comparing the measured displacement of a particular marker bed with the maximum displacement recorded by any of the markers anywhere across that thrust (Fig. 3e, f. g). Slower propagation of the thrust tip relative to slip develops in weaker units and is considered to create displacement profiles with steeper gradients on D-D plots, while gentle profiles correspond to more rapid propagation of the thrust tip relative to slip in more competent units (e.g. Williams and Chapman, 1983; Ferrill et al., 2016). Displacement on faults is generally thought to be time-dependent with older portions of faults thereby accruing the greatest displacement (e.g. Ellis and Dunlap, 1988; Hedlund, 1997; Kim and Sanderson, 2005). The point of maximum displacement on a D-D plot is therefore considered to correspond with the site of fault nucleation (e.g. Ellis and Dunlap, 1988; Peacock and Sanderson, 1996; Hedlund, 1997; Ferrill et al., 2016).

In our examples of Model 1 overthrust ramps (Fig. 4a-i), displacement generally reduces towards the upper reference point $(\mathrm{R})$, with larger displacements corresponding to greater uplift of the hangingwall while the footwall maintains broadly similar elevations (Fig. 3e). In detail, displacement profiles are marked by a series of 'steps' that correspond to where the thrust ramps cut detrital-rich markers that are considered to be more competent (Fig. 4c-i). In our examples of Model 2 underthrust ramps (Figs. 5a-g, 6a-i), displacement generally increases towards the upper reference point $(\mathrm{R})$, with larger displacements corresponding to greater lowering and depression of the footwall, while the hangingwall displays only slight to moderate uplift (Fig. 3f). In some cases, the greatest displacement is developed in the uppermost competent bed (e.g. orange marker bed in Fig. 5b, c) suggesting that the ramp initiated at this level and largely propagated downwards. In our examples of Model 3 mixed wedge ramps (Fig. 7a-g), displacement generally increases towards the centre of the ramp (e.g. Fig. 7d) or the upper reference point (R) (Fig. 7d, g) with larger displacements corresponding to greater uplift or depression of the hangingwall and footwall respectively (Fig. 3d, g). The irregular profiles on some D-D plots to some extent reflects the variable stratigraphy comprising weaker aragonite-rich and more competent detritalrich beds that are cut by the overthrust or underthrust ramps (e.g. Figs. 4i, 5c respectively). The general relationships shown on D-D plots across thrust ramps in the three models is summarised in Table 1c. 


\subsection{Variations in stratigraphic thickness across thrust ramps}

The normal stratigraphic thickness of a sequence is measured orthogonal to bedding in an area removed from immediate deformation (Fig. 8a) (Alsop et al., 2017a). The normal stratigraphic thickness of units may then be compared with the orthogonal thickness of bedding measured in the hangingwall $(\mathrm{Hw})$ and footwall $(\mathrm{Fw})$ of thrust ramps (the Hw or Fw 'ramp thickness' defined in Fig. 8a).

Our data show that in Model 1 overthrusts there is a \% increase in the thickness of Hw ramps compared to normal thicknesses, while Model 2 underthrusts and Model 3 mixed wedge ramps are marked by a \% reduction in Hw thicknesses (Fig. 8b, c). Footwall ramp thicknesses are generally thinned compared to normal footwall thicknesses in Model 2 and Model 3 ramps (Fig. 8b), while Fw ramps thicknesses are usually less than equivalent Hw ramp thicknesses across all overthrust, underthrust and mixed wedge models (Fig. 8c). These patterns are considered to relate to folding and shearing of the 'active' hangingwall to create hangingwall antiforms in overthrusts, and the footwall being deflected and pushed downwards in underthrusts to create footwall synforms. The mixed wedge model involves deformation both above and below the thrust ramp and leads to a \% thinning in both the Hw and Fw sequences (Fig. 8b), although Fw are generally reduced to a greater extent than Hw (Fig. 8c). The general relationships between thickness of marker layers across thrust ramps in the three models is summarised in Table 1d.

\subsection{Values of relative 'Stretch'}

The hangingwall and footwall thickness of a chosen stratigraphic package can be measured parallel to transport along the individual thrust ramp, to define the stratigraphic 'cut-off thickness' above and below the thrust plane, respectively (Fig. 8a). The relative stretch $\left(\varepsilon_{\mathrm{r}}\right)$ represents the ratio of the measured hangingwall $\left(l_{\mathrm{h}}\right)$ and footwall $\left(l_{\mathrm{f}}\right)$ cut-off lengths, (where $\varepsilon_{\mathrm{r}}=$ $1_{h}$ over $1_{f}$ ) (e.g. Noble and Dixon, 2011, p.72) (Fig. 8a). Fault-propagation folding (FPF) adjacent to thrust ramps locally increases the dip of bedding and thereby reduces the cut-off lengths of beds (e.g. Noble and Dixon, 2011). As stretch is defined by the length of hangingwall cut-offs compared to those in the footwall, then the creation of hangingwall antiforms will result in smaller values of stretch $(<1)$, while the development of footwall synforms will lead to larger $(>1)$ values of stretch.

Within the case study, overthrust Model 1 ramps display hangingwall antiforms with cutoff lengths that are relatively thinned compared to equivalent footwall sequences (Figs. 4b, c, $8 \mathrm{~d}$ ), thereby resulting in stretch values $<1$ ( $\varepsilon_{\mathrm{r}}$ averaging 0.409 ) (Fig. 8e). Underthrust Model 2 ramps are marked by footwall synforms with cut-off lengths that are relatively thinned compared to equivalent hangingwall sequences (Figs. $5 \mathrm{~d}, 6 \mathrm{c}, 8 \mathrm{~d})$, thereby resulting in stretch values $>1\left(\varepsilon_{\mathrm{r}}\right.$ averaging 1.403) (Fig. 8e). The mixed Model 3 ramps display thinned footwall cut-offs compared to hangingwalls, leading to stretch values $>1$ ( $\varepsilon_{\mathrm{r}}$ averaging 1.244) (Fig. 8e). In overthrust, underthrust and mixed examples, hangingwall ramp thicknesses are generally greater than footwall ramp thicknesses for equivalent beds (Fig. 8e), with footwall ramps displaying a 
reduction in \% thickness compared to normal footwall thicknesses (Fig. 8g). In overthrust Model 1 examples, hangingwall ramp thicknesses are increased relative to normal thicknesses, whereas they are reduced in underthrust Model 2 and mixed Model 3 examples (Fig. 8f). FPF is favoured by rapid reductions in displacement towards fault tips that reflect higher slip/propagation ratios $(>1.5)$ and high values of relative stretch (Noble and Dixon, 2011, p.73). We recognise such variations in both the hangingwall during classic overthrusting (Model 1) to create hangingwall antiforms, and also in the footwall during underthrusting (Model 2) to generate footwall synforms. In mixed Model 3, lower values of stretch $\left(\varepsilon_{\mathrm{r}}=1.244\right)$ compared to underthrust Model $2\left(\varepsilon_{\mathrm{r}}=1.403\right)$ indicates that FPF and rapid displacement gradients may be less significant in the examples shown (Fig. 7). The general relationships between stretch of marker layers across thrust ramps in the three models is summarised in Table 1e.

\subsection{Variable dips of thrust ramps}

It has previously been noted that there may be significant reductions in the angle of dip of thrust ramps with increasing displacement (e.g. Strayer and Hudleston, 1997, p.559). Similar relationships have also been observed in the Lisan Formation (Alsop et al. 2017b, their fig. 5) and are examined further here.

Within the case study, Model 1 overthrust ramps display a similar span of dip angles as Model 2 underthrust and Model 3 mixed ramps that range between $\sim 10^{\circ}$ and $50^{\circ}$ (Fig. $8 \mathrm{~h}$ ). Although there is no discernible variation in the dip of thrust ramps with the values of stretch that are recorded across ramps in each model (Fig. $8 \mathrm{~h}$ ), there is a greater $\%$ increase in hangingwall thickness as the ramp angle decreases in Model 1 overthrust ramps (Fig. 8i). Model 2 underthrust ramps show a slight increase in the \% thinning of the hangingwall as the angle of ramp dip increases (Fig. 8i). The footwall thicknesses show an increased \% thinning with steeper dips in Model 1 overthrust ramps in a pattern that is mirrored (to a lesser extent) in Model 2 underthrust ramps (Fig. 8j). The data from Model 3 mixed ramps only varies from dips of $10^{\circ}$ to $22^{\circ}$ and so does not encompass a broad enough range to observe clear relationships (Fig. 8i, j). The general relationship between angle of dip of the thrust ramp and thickness of adjacent sequences in the three models is summarised in Table $1 \mathrm{f}$.

In general, the dip of thrust ramps progressively reduces upwards towards the reference point in all 3 models (Figs. 4d, f, i, 5c, 6e, i, 7d, g). In Model 1 overthrusts, this results in lower angles of ramp dip corresponding to less displacement across the ramp (Fig. 4d, f, i), whereas in Model 2 underthrusts, the more gently dipping upper portions of ramps are marked by the greatest displacements (Figs. 5c, 6e, i). Model 3 mixed ramps generally show increased displacement with a reduction in the dip of thrust ramp up towards the reference point (Fig. $7 \mathrm{~d}$, g). In detail, overthrust ramps in Model 1 display a series of steps where locally increased dips midway up the ramp correspond to a relative increase in displacement where ramps cut competent units (Fig. 4d, f, i). Examples of Model 2 underthrust ramps generally display less irregular dip profiles (Figs. 5c, 6e, i,), while Model 3 mixed ramps are marked by more gentle dips (Fig. 7d, g). Reductions in the angle of ramp dips may form towards lower 'floor' detachments and upper 'roof' detachments in overthrusts (e.g. Fig. 4b), underthrusts (e.g. Figs. 
$5 b, 6 d)$ and mixed ramps (e.g. Fig. 7b) potentially reflecting the linkage of ramps and detachments to create duplexes. The general relationship between angle of dip of the thrust ramp and displacement of adjacent sequences in the three models is summarised in Table $1 \mathrm{~g}$.

\section{Fault propagation folding and variation in bedding dip next to thrust ramps}

Fault-propagation folds (FPF) may be defined as "folds developed at the tip of a propagating fault" (Ramsay and Huber, 1987, p.558) and typically form as a consequence of variable displacement along thrust ramps (e.g. Williams and Chapman, 1983; Chapman and Williams, 1984; Suppe and Medwedeff, 1990). Where a fault tip has been inhibited or ceased to propagate then continuing displacement is accommodated by folding of incompetent beds beyond the fault tip (e.g. Ferrill et al., 2016, p.10). Although some authors note that FPF form above the tip-lines of thrusts and thereby intrinsically link such folds to upwardly propagating thrusts (e.g. Fossen, 2016, p.366), it has also been suggested that FPF creates footwall synforms that develop due to the downward propagation of thrusts that initiate in overlying competent beds (e.g. Ferrill et al., 2016)

In our examples of Model 1 overthrust ramps, hangingwall antiforms are well-developed above the thrust ramps while footwalls remain relatively planar and undeformed (Fig. 4a-i). Folding is not observed further away from these thrusts which are interpreted as FPF. Hangingwall antiforms are increasingly developed higher up the thrust ramps where displacement is reducing towards the overlying reference point (R) (Fig. 4a-f). Hangingwall antiforms may also develop lower down thrust ramps adjacent to local variations in displacement associated with lithological heterogeneity (Fig. 4g-i).

In our examples of Model 2 underthrust ramps, FPF is represented by footwall synforms and hangingwall antiforms (Figs. 5a-g, 6a-i). Footwall synforms are in some cases better developed than hangingwall antiforms (Fig. 5f, g), and in general are more enhanced lower down the thrust ramp where displacement is reducing (Figs. 5d, e, 6c, d). Footwall beds higher up the thrust ramp where displacement is greater locally increase their dips towards the ramp orientation (Figs. 5f, g, 6c, d, f-h). Rotation of bedding in the footwall is accompanied by a marked reduction in bedding thickness achieved through $\mathrm{mm}$-scale attenuation of laminae while preserving the intricate stratigraphy (i.e. individual laminae and their stratigraphic position are still preserved while being significantly reduced in thickness) (Figs. 5b, d, e, 6c, d).

In our examples of Model 3 mixed wedge ramps, FPF is only poorly developed potentially reflecting more gentle displacement gradients and lower values of stretch $\left(\varepsilon_{\mathrm{r}}=1.244\right)$ (see section 4.4). However, both the hangingwall and footwall beds display rotation towards the gently-dipping thrust ramps (Fig. 7a-f). These rotations are associated with thinning and attenuation of beds, which are particularly pronounced in the footwall of the ramps (Fig. 7a, b). The general relationships between FPF and dip of bedding adjacent to the thrust ramps in the three models is summarised in Table $1 \mathrm{~h}$, i.

\section{Local variation in ramp types}




\subsection{Differing ramp styles and displacement patterns}

Examples of overthrust ramps, underthrust ramps and mixed wedge ramps may be developed adjacent to one another (e.g. Fig. 9a-g). An overthrust ramp (labelled A in Fig. 9b) uplifts the hangingwall leading to excision of some stratigraphy by the overlying 'roof' thrust. Conversely, an underthrust ramp (labelled B in Fig. 9b) locally depresses the footwall leading to excision of stratigraphy from below the orange marker horizon along the underlying 'floor' detachment. A mixed ramp (labelled C in Fig. 9b) depresses the footwall higher up the ramp, while the equivalent dark grey marker in the hangingwall is uplifted and locally cut by the roof detachment. Displacement-distance plots show a reduction in displacement up along the overthrust ramp that gradually becomes more gently dipping (Fig. 9b, c), whereas the underthrust ramp is marked by increasing displacement upwards with the ramp angle locally increasing and then decreasing towards the reference point (R) (Fig. 9d, f, g). The mixed ramp displays only limited variation in displacement, although the dip of the ramp progressively increases upwards (Fig. 9e, f, g). In detail, overthrust ramp A and hybrid ramp $\mathrm{C}$ display limited $\left(\sim 10^{\circ}\right)$ variation in ramp dip marked by maximum displacements of $60-70$ mm (Fig. 9c, e). However, underthrust ramp B shows a large $\left(\sim 30^{\circ}\right)$ variation or 'step' in dip associated with only limited displacement $(<25 \mathrm{~mm})$ where the ramp is steepest (Fig. 9d). Given that these adjacent overthrust, underthrust and hybrid ramps are developed within 50 $\mathrm{cm}$ of one another and cut identical mechanical stratigraphy (Fig. 9a, b), it suggests that continued movement and increased thrust displacement may partially conceal earlier steps and local variations in ramp dip.

In summary, this example shows that differing ramp types may develop adjacent to one another in the same stratigraphy and form part of the same fold and thrust sequence. This suggests that in this case mechanical stratigraphy may play only a limited role in determining ramp type and that other factors such as local strain rates and the influence of existing thrusts and thrust sequences may be significant.

\subsection{Hangingwall loading and footwall failure}

Overthrust ramps locally raise stratigraphy above its regional leading to it being cut by overlying detachments (Fig. 10a-d). Displacement decreases up overthrust ramps while the dip of the ramp increases (Fig. 10c). In some cases, extensional faults that dip in the same direction as thrust ramps, but are slightly steeper, are cut by the thrust ramps and the underlying 'floor' or basal detachment (Fig. 10b, d). Displacement reduces down the normal faults (e.g. Fault B in Fig. 10d), suggesting that the normal fault nucleated close to the intersection with the overlying thrust ramp and propagated downwards resulting in a slight back-tilting of the hangingwall to the normal fault (e.g. Fault B in Fig. 10d). The close association between the normal faults and thrust ramps, both of which are subsequently cut by the basal detachment, suggests that normal faults and thrusting are closely linked. Although it is difficult to determine the exact cause, one possibility is that the normal faults are formed by excess loading and failure of the footwall to the ramp created during overthrusting of the hangingwall 'block'. The cross-cutting and timing relationships clearly show that the upper and lower detachments that bound the system 
propagated across the thrust ramps and normal faults at a slightly later stage. This suggests that in this case, the thrust ramps were not related to cessational' late-stage strain created during 'lock-up' of the thrust system when bounding detachments were already developed.

\subsection{Ramps marking backthrusts}

The concept of footwalls 'wedging' and being depressed beneath the adjacent hangingwall has been suggested to develop along backthrusts associated with gravity-driven FATS (Alsop et al., 2017b). These authors stress that there is no actual movement of the hangingwall back up the regional slope and that it is the footwall that is forced down beneath the ramp as it moves downslope. In the examples we show (Fig. 10e, f), the greatest displacement is in a thick (orange) detrital marker and then diminishes both up and down the thrust ramp to where the ramp joins bedding-parallel upper and lower detachments (Fig. 10f, g). The area of greatest displacement coincides with gentle dips along the thrust ramp, with the footwall being depressed below regional elevations (Fig. 10f, g). The competent orange marker horizon is locally pinched and thinned beneath the gently-dipping $\left(\sim 10^{\circ}\right)$ backthrust (Fig. $10 \mathrm{e}, \mathrm{f}$ ). The ramp cut-off angle in the competent (orange) marker horizon is steeper than the present dip of the fault (Fig. 10e, f). This suggests that the initial dip of the ramp may have been steeper and was subsequently reduced as the footwall moved downslope and was 'wedged' downwards beneath the backthrust. More steeply dipping backthrusts of up to $\sim 75^{\circ}$ are described by Alsop et al. (2017b, p. 58, their fig. 5b) who discuss thickening in the footwall of backthrusts elsewhere in the Lisan Formation. They show that pronounced thickening generally occurs beneath steep back thrusts as the footwall is 'wedged in' from further upslope. The development of the backthrust and its overlying upper detachment directly beneath a prominent detrital horizon suggests that in this case, the overall position of the thrusts may be controlled by the mechanical effects of stratigraphy (Fig. 10e, f).

\section{Discussion}

\subsection{What 'end-member' thrust ramp models are applicable to gravity-driven FATS?}

The majority of previous studies on FATS have assumed that the hangingwall to thrusts is actively deformed and uplifted while the footwall remains passive and undeformed. This may reflect inherent space and accommodation issues if the footwall moves downwards to deeper levels (Ramsay, 1992). Those studies that have proposed footwall deformation and development of underthrusts have suggested that this requires deep burial, otherwise the hangingwall is more likely to move and uplift the surface (e.g. Ramsay, 1992; Berlenbach 1995). However, we have shown in this study that underthrusts may form in unlithified sediments very close $(<5 \mathrm{~m})$ to the surface and do not therefore require significant depths of burial.

We stress that in gravity-driven FATS the active motion is directed downslope, and the beds in the footwall to underthrust ramps, or hangingwall to downslope-verging backthrust ramps, are not considered to independently translate back up the regional slope (see discussion in Alsop et al. 2017b). Within the gravity-driven FATS, variable rates of downslope-directed translation create different thrust and backthrust geometries. Overthrust ramps are formed by the 
hangingwall moving downslope more rapidly than the footwall, with the hangingwall being uplifted above regional elevations (Table 1a; Fig. 11a). Underthrust ramps are also created by the hangingwall translating more rapidly downslope than the footwall, which in this case leads to the hangingwall over-riding the footwall which is thereby depressed below its regional elevation (Table 1a; Fig. 11b) (see discussion in Alsop et al. 2017b, 2021). Mixed 'wedge' models invoke components of hangingwall uplift and footwall depression during continued downslope movement (Table 1a; Fig. 11c). In the examples we have examined, the various types of thrust ramp may or may not be cut by overlying ('roof') and underlying ('floor') bounding detachments (Table 1b). Thrust ramps may be inferred to have formed before detachments where thrusts are isolated from detachments (e.g. overthrusts (Fig. 4e, g) underthrusts (Fig. 6c, d); mixed ramps (Fig. 7e, f). Alternatively, thrusts may be clearly cross-cut by detachments, or thrusts cut extensional faults and both are then cut by lower detachments (Fig. 10a-d). This is important as it demonstrates that in this case, detachments formed at a later stage and the various types of thrust ramps are therefore not a late-stage feature linked to cessational strain and lock-up of the thrust system.

\subsection{How do displacement-distance patterns vary in different thrust ramp models?}

The classic fault-bend fold model (Suppe, 1983) and the fault-propagation fold model (Suppe and Medwedeff, 1984, 1990) both assume that: a) the hangingwall of a thrust ramp is transported over a stationary footwall; b) that the footwall itself is undeformed; and c) that the thrust ramp propagates directly upwards from the tip of the basal detachment (see discussion in McConnell et al., 1997, p.257). These basic principles are inherent in many of the variants that have stemmed from these idealised kinematic scenarios (e.g. see Chester and Chester, 1990), although the premise that the ramp propagates upwards from the tip of the basal detachment is debated with many authors suggesting that ramps and associated fault-propagation folds may initiate in competent horizons directly above any future basal detachment (e.g. Eisenstadt and De Paor, 1987; Ellis and Dunlap, 1988; Uzkeda et Al., 2010; Ferrill et al., 2016). It is this scenario of ramps initiating above basal detachments that is explicitly shown in our overthrust, underthrust and mixed 'wedge' ramp models (Figs.1a, e, g, 11a, b, c). However, the overthrust model incorporating an upward-propagating ramp may in some cases result in similar geometries to ramps propagating directly from an underlying basal detachment. An important element of the fault-propagation fold model is that fault displacement is considered to decrease up-section across the hangingwall ramp (see summary in McConnell et al., 1997, p.257). These general patterns of displacement decreasing up the thrust ramps are shown in the Model 1 ramps of this study (e.g. Figs. 4a-i, 11a), as well as in some previous studies of gravity-driven FATS (e.g. Alsop et al. 2018). Local variations in displacement may reflect mechanical controls exerted by stratigraphy (Fig. 4c-i), although the overall pattern of decreasing displacement up the ramp characterises overthrust Model 1 ramps (Table 1c, Fig. 11a).

Previous authors including Williams and Chapman, (1983), Ramsay, (1992), Morley, (1994), McConnell et al., (1997), Uzkeda et al., (2010), Ferrill et al., (2016) have also recognised that displacement may decrease down the thrust ramp from a point near the top, and infer that these faults "may propagate down-dip in a direction opposite to that typically displayed in 
models" (McConnell et al., (1997, p.264). Such underthrust Model 2 ramps are characterised in this study by displacement markedly decreasing down the thrust ramp (e.g. Figs. 5a-g, 6a-i, 11b). Similar patterns with displacement reducing down a downward propagating thrust towards an underlying basal detachment have also been recognised on a larger scale on seismic sections across gravity-driven FATS by Morley et al. (2017, p.184, their fig. 23). In the case study, the largest displacement may correspond with the uppermost competent detrital marker beds where the ramp is considered to have initiated and propagated downwards to create Underthrust Model 2 ramps (e.g. Fig. 5b, c, Table 1c). A number of authors have also noted that thrust ramps may initiate at a point generally marked by the greatest displacement and then propagate both upwards and downwards from that site (e.g. see review in Ferrill et al., 2016) (Fig. 11c). These mixed wedge Model 3 ramps are highlighted in the present study by displacement peaks forming in the central parts of ramps that correspond with, or are immediately below, competent detrital markers (e.g. Figs. 7c, d, 9b, e, Table 1c).

Displacement patterns are also reflected in the dip of thrust ramps with Strayer and Hudleston, (1997, p.559) noting that there is 'significant flattening of the ramp angle with increasing displacement' and this is especially the case where the footwall is deformed. This general relationship is shown in the case study where individual ramps display $10^{\circ}$ to $15^{\circ}$ reductions in dip angles as displacement increases up Model 2 underthrust ramps (e.g. Figs. 5c, 6e, 6i, 9d, 11b) and Model 3 mixed ramps (e.g. Figs. 7d, g, 9e, Table 1g). Although displacement-distance patterns may be subsequently masked by continued movement across faults and are sensitive to mechanical stratigraphy that is cut by the thrust, they still provide a useful tool to help distinguish and discriminate different models of thrust ramp development (e.g. McConnell et al., 1997, p.266) (Table 1c).

Relationships between the overall dip of thrust ramps and the thickening of hangingwall units have been analysed in sandbox experiments by Koyi and Maillot (2007). These authors show that the amount of hangingwall thickening above thrust ramps reduces with lower overall angles of ramp dip, lower coefficients of friction along the ramp, and where the footwall to the ramp is non-rigid and undergoes deformation. In the present study, the hangingwalls of Model 1 ramps undergo greater thickening where the dip of the ramp is less (Fig. 8i). This may however reflect larger displacement and deformation along gently dipping ramps that form close to the sediment-water interface. Larger displacement along such shallow overthrusts results in translation sub-parallel to the lakebed as the weak sediments are unable to build significant topography (see Alsop et al. 2017b, their fig. 5). This is exemplified in our data where overthrust ramps with larger $(\sim 2000 \mathrm{~mm})$ displacement dip at $<25^{\circ}$ (Fig. 4 d), whereas as ramps with modest displacement $(\sim 600 \mathrm{~mm})$ are more steeply dipping $\left(>30^{\circ}\right)$ (Fig. 4 d, Table $\left.1 \mathrm{~g}\right)$.

Where the footwall is also deformed in Model 2 and 3 ramps, then hangingwall thickening is significantly less and may be thinned, while the footwalls also undergo thinning (Fig. 8j). Once again, more steeply dipping ramps are associated with smaller displacements, even where different ramp types form adjacent to one another in the same sequence (e.g. Fig. $9 \mathrm{~d}, \mathrm{e})$. It therefore appears in the case study that the amount of displacement may be a significant factor governing the relationship between dip of ramps and the thickening or 
thinning of hangingwall and footwall sequences. However, as it is not possible to measure coefficients of friction along thrust ramps in the field examples, we are unable to precisely evaluate the role that friction played in their development.

\subsection{How is variable displacement accommodated across thrust ramps?}

The raising of hangingwall blocks during overthrusting may simply be accommodated close to the Earth's surface by areas of surficial uplift creating ridges and bathymetric expression in subaqueous FATS (e.g. Nugraha et al., 2020). However, the consequences of underthrusting and movement of footwalls into deeper levels requires further consideration.

\subsubsection{Fault Propagation Folding}

One mechanism by which displacement gradients at the tip of a thrust may be accommodated is by fault propagation folding (FPF) (e.g. Suppe and Medwedeff, 1984, 1990). Hangingwall antiforms are considered to form at the leading edge of a propagating overthrust due to relatively fast rates of slip on a relatively slowly propagating thrust (e.g. Williams and Chapman, 1983, p.569) (Table 1h). Folding at the fault tip leads to a reduction in the value of stretch (see section 4.4), with values as low as 0.3 recorded from the case study, and only a few overthrusts generating stretches of 0.85 (Fig. 8e, Table 1e). These values are generally lower than recorded from thrusts cutting lithified rocks and are consistent with overthrusts forming in weak unlithified sediments (see Alsop et al. 2017a).

Underthrusts develop values of stretch $>1$ because footwall synforms develop beneath the thrust ramp (Figs. 5a, b, 8e-g, Table 1e). It has been suggested that footwall synforms are generated by the fault-tips of thrust ramps that propagated downwards (e.g. Williams and Chapman, 1983; Ramsay, 1992; Morley, 1994; McConnell et al., 1997; Uzkeda et al., 2010; Ferrill et al., 2016). The displacement distribution along underthrusts indicates that footwall synforms and thrusts developed contemporaneously, creating what McConnell et al. (1997, their fig. 15) have termed 'inverted fault propagation folds'.

Mixed wedge ramps also generally form stretch values $>1$, although some values $<1$ reflect the development of hangingwall antiforms (Fig. 8e-g). The development of both hangingwall antiforms and footwall synforms can create 'wedge' folds (e.g. Cloos, 1961). Models run by Strayer and Hudleston, (1997, p.559) resulted in wedge folds being developed in the softer layers both above and below the thrust ramp. More recently, a number of 'double-edge fault propagation fold' models have been developed where folds are created in both the hangingwall and footwall of the thrust ramp that propagates at either tip (e.g. Tavani et al., 2006; Uzkeda et al., 2010). Such models make a number of assumptions including flexural slip, preservation of bed thicknesses and relatively 'fixed' footwalls that may not be pertinent to deformation in unlithified sediments. The limited development of FPF adjacent to mixed ramps in the study area suggests that rapid displacement gradients at fault tips may be less significant than in overthrust and underthrust ramps.

FPF is generally best developed adjacent to where thrust ramps display less offset and displacement gradients are at their greatest towards the propagating fault tip (e.g. McConnell et 
617

618

al., 1997, p.264). In the case of overthrust ramps, FPF are therefore best developed in the hangingwall towards the upper part of the ramp (Figs. 4c-i, 11a, Table 1h), whereas in underthrust ramps folds are generated in the footwall lower down the ramp (Figs. 5a-c, 11b). This relationship suggests that folding and thrusting are intimately related and do not in this case correspond to earlier folds being cut by later thrusts (i.e. break-thrust folds) (e.g. Ferrill, 1988; Fischer et al., 1992; see discussion in Morley 1994; Thorbjornsen and Dunne, 1997; Alsop et al. 2021). If we follow the assertion that "folds form on the side of the fault that is displaced in the direction of fault propagation" (McConnell, 1997, p.264), then FPF form a reliable guide to where displacement is being accommodated at fault tips.

\subsubsection{Differential Vertical Compaction}

It is increasingly recognised that both rocks and sediments may undergo significant components of layer-parallel compaction prior to the development of FATS (e.g. Koyi et al., 2004; Butler and Paton, 2010; Alsop et al. 2017a). Indeed, Ramsay (1992, p.199) showed that displacement of underthrust 'wedges' of competent lithified dolostone beds was partially accommodated by homogenous deformation of weaker shales and distortion of the ammonites they contained (Fig. 1h). The ability of unlithified sediments to absorb deformation by compaction may also provide a mechanism to accommodate underthrusting deeper in the sediment pile.

Differential vertical compaction (DVC) may be recognised by comparing the normal stratigraphic thicknesses of 'undeformed' beds with equivalent units in the footwall or hangingwall of the thrust ramp (Fig. 8a). In our analysis, we compare hangingwall and footwall thickness with 'normal' thicknesses in sections removed from thrust ramps. In ideal overthrust ramps (Model 1), the footwall remains undeformed and beds retain original thicknesses (Fig. 11a, Table 1d), although our data show that footwall thicknesses may locally increase or decrease (Fig. 8b). In Model 2 and Model 3 ramps where a component of underthrusting is developed, the footwall ramp thicknesses are generally thinned compared to normal footwall thicknesses and those in the hangingwall (Fig. 8b, c, Table 1d). These relationships are exemplified in our case study where beds directly beneath underthrust (Model 2) ramps may be thinned by up to $25 \%$ (Fig. 5b) or 35\% in some cases (Fig. 6c, d), while mixed (Model 3) ramps can display even more extreme thinning of $\sim 50 \%$ (Fig. 7a-g). This thinning is achieved by reductions in individual layer thickness rather than excision of complete beds and is attributed to DVC as the footwall to the underthrust and mixed ramps is pushed down beneath the over-riding hangingwall (Fig. 11b, c).

Although other factors such as along-strike lateral expulsion of sediment cannot be excluded and may have operated in the footwall of ramps elsewhere in the Lisan Formation (Alsop et al., 2020c), we suggest that DVC plays a significant role in absorbing vertical displacement. The development of footwall synforms and DVC may locally help accommodate thrust ramps where a component of underthrusting has operated. The effect of DVC on bed thickness may also influence estimates of displacement and stretch for these beds. It is likely that DVC is most developed close to the surface where significant porosity is preserved, and in this respect is similar to lateral compaction that also increases towards the sediment surface (see 
discussion in Alsop et al. 2017a). However, it is also possible for DVC to develop in compacted rocks, with Morley et al. (2021) suggesting that variations in vertical shortening marked by anticlines displaying loss of amplitude upwards or synclines dying out downwards, may be accommodated by bed-parallel pressure solution seams in adjacent rocks. The role of DVC across a range of settings and states of lithification may therefore be more significant than hitherto realised.

\section{4. d) How can different thrust ramp models be distinguished?}

We have identified a range of parameters that may be used to help distinguish different thrust ramp models that are summarised in Table 1a-i. We here highlight some of the key factors used to establish if a thrust represents an end-member overthrust ramp (Model 1) or underthrust ramp (Model 2).

i) Marker beds remain at or above regional elevation during overthrusting, whereas they are depressed below regional during underthrusting.

ii) The hangingwall of overthrust ramps is uplifted and potentially cut by upper detachments, whereas the footwall of underthrust ramps is depressed and potentially cut by lower detachments.

iii) The greatest displacement generally develops lower down overthrust ramps and decreases upwards, whereas larger displacements form high up underthrust ramps and reduce downwards.

iv) Hangingwall sequences and cut-offs are relatively thinned (stretch $<1)$ in overthrust ramps, while footwall sequences and cut-offs are thinned in underthrust ramps (stretch $>1$ ).

v) Displacement reduces with decreasing dips up overthrust ramps, whereas it increases with decreasing dips up underthrust ramps.

vi) Fault propagation folding is marked by hangingwall antiforms formed above overthrust ramps, whereas footwall synforms develop below underthrust ramps.

In all of these cases, local variations may complicate relationships. It is possible to develop neighbouring hangingwall antiforms and footwall synforms if the thrust ramp in question is not a 'pure' overthrust or underthrust end-member but contains minor components of footwall or hangingwall deformation respectively. Similarly, displacement-distance profiles can be strongly modified by mechanical stratigraphy that influenced nucleation sites of original ramps. Nevertheless, the criteria summarised in Table 1 do provide a useful guide to endmember scenarios and collectively form a reasonably robust synopsis to determining the ramp type.

\subsection{What controls the different thrust ramp models?}

The majority of thrust ramps that are observed in orogenic belts and gravity-driven FATS appear to show overthrust Model 1 relationships with the hangingwall undergoing uplift and the 
footwall behaving more passively. This appears to be especially the case if thin-skinned thrusts are detaching on a rigid basement in an orogenic setting (e.g. Boyer and Elliot, 1982; Morley, 1986: Boyer, 1992 Twiss and Moores, 2007; Fossen, 2016, p.363). The question arises as to why some thrust ramps display contrasting relationships with depression of footwalls as in the underthrust and mixed ramp models.

When analysing outcrops of underthrust and mixed ramps, Ramsay (1992) considered the footwall and hangingwall lithologies to have similar competency. However, Berlenbach (1995, p.40) noted that areas of underthrusting in orogenic settings are restricted to places where the hangingwall stratigraphy is significantly more competent than the footwall. It is these differences in competency that Berlenbach (1995) considered to be controlling factors on overthrust or underthrust development. Many models implicitly invoke a deformable hangingwall that is translated over a 'rigid' footwall (e.g. Rosas et al., 2017 and references therein). However, deformation of weak footwalls such as represented by shales is commonly reported (e.g. see Morley et al., 2017 p.217 for a recent review). Numerical models run by Strayer and Hudleston (1997) employ differential horizontal shortening combined with a deformable lower block rather than a rigid base plate (model D in their fig. 3). Models permitted internal deformation of both the hangingwall and footwall to the thrust ramp, with deformation of the footwall largely dependent on the rigidity of the strata below a stiff overlying layer (Strayer and Hudleston, 1997, p.562). In general, the style of FPF or 'wedge' folding is considered to be controlled by the relative resistance to foreland (downslope) translation, versus the internal deformation of the layers and the extent to which the footwall is deformable (Strayer and Hudleston, 1997, p.564).

In the case study, the Lisan Formation has the advantage that the aragonite-rich and detrital-rich beds form a bilaminate sequence 'comprising only two different types of layers which alternate with each other' (Price \& Cosgrove 1990, p. 307). This simplified sequence was highlighted by Alsop et al. (2020c p.85), although it should be stressed that layers need not be of equal or regular thickness (thereby leading to multilayer packages), or alternatively, they may be single-layer thicker detrital-rich beds that act as competent horizons (e.g. Alsop et al. 2017a; 2020c). Thicker more competent beds are observed lower down overthrust ramps (e.g. Fig. 4a-d, g-i), whereas they are typically found higher up underthrust ramps (Figs. 5a, b, 6a-i). Examples of mixed ramps display more competent beds midway up the thrust ramp that may correspond with displacement maxima and sites of ramp nucleation (Fig. 7a-d). The initiation of ramps in overlying competent beds and downwards propagation of thrusts to create footwall synforms to underthrusts is similar to the model proposed by Ferrill; et al. (2016) in lithified sequences. More competent detrital beds may also be found overlying upper detachments associated with overthrust (Fig, 5a, b) and mixed (Fig. 7a, b, c) ramps in a manner similar to the models of Strayer and Hudleston (1997, p.562). It would therefore appear that mechanical stratigraphy, and the position of competent layers within the deforming sequence, play a major role in determining ramp types. However, the juxtaposition of ramps of differing style (Fig. 9a-g) in otherwise identical stratigraphy sounds a note of caution that other factors such as strain rates, evolutionary history of adjacent thrusts, and fluid migration may also influence ramp development.

\subsection{What are the consequences of different thrust ramp models?}


Overthrust ramps (Model 1) may build topography on the sediment surface, with surficial uplifts representing an apparently straight forward mechanism to accommodate raising of the hangingwall above regional. However, difficulties in building topography are recognised in some gravity-driven fold and thrust belts affecting weak sediments. Alsop et al. (2020c). suggest that in some cases overthrusts may be reactivated soon after inception and collapse back down the ramp potentially leaving extensional offsets. The consequence of this 'back-collapse' is that the fold and thrust system does not develop a simple critical taper (Davis et al., 1983; Davis and Engelder, 1985; Woodward, 1987; Dahlen, 1990; Koyi, 1995). The recognition in this study of extensional faults in the immediate footwall of ramps (Fig. 10d) that are both cut by underlying basal detachments may also contribute to this broadly coeval collapsing process.

Underthrust (Model 2) and mixed ramps (Model 3) are considered to accommodate at least some of the shortening by the footwalls of ramps being depressed below regional. The crests of stratigraphic markers preserved at the same level in the hangingwall of thrusts, despite variable displacement across the thrusts (e.g. Fig. 6f, g), together with the depression of footwall markers towards underlying detachments (e.g. Fig. 6c, d), may suggest that some footwall deformation and differential vertical compaction has occurred to accommodate this movement. Underthrust (Model 2) and mixed ramps (Model 3) marked by DVC and a general lack of hangingwall uplift therefore lack, or create only very subdued, surface topography.

A lack of surface topography linked to some FATS associated with MTDs has been noted by Frey-Martinez et al., 2005, 2006). Previous analysis of deforming wedges and critical tapers in the Lisan Formation indicate taper angles of just $0.19^{\circ}$ to $0.38^{\circ}$ (Alsop et al., 2017a, 2018). This is an order of magnitude less than in accretionary complexes (see discussion in Alsop et al., 2018) and suggests that underthrusting or mixed thrusts associated with DVC may stifle the build-up of topography and consequently reduce critical tapers in gravity-driven FATS. Although the exact role of fluid pressures and hence friction along the detachments which affects the critical taper in the case study are difficult to ascertain, the presence of gouge injected into sediments above detachments (e.g. Alsop et al., 2018, p.109, their fig 7j) indicates high pore fluid pressures and reduced coefficients of friction. Friction and ramp angles have previously been shown by Koyi and Maillot (2007) to influence the geometry and thickening of beds adjacent to thrust ramps in experimental studies. It is therefore likely that fluids will influence the nature of deformation along the detachments in the case study and thereby affect critical tapers.

Significant vertical compaction of sediments may lead to a range of other issues affecting the use of constant area balancing techniques during restoration of thrust systems Area balancing has been discussed by a range of authors (e.g. Hossack, 1979; Cooper et al., 1983; Cooper and Trayner, 1986; Mitra, 1992) and "assumes that the original cross sectional area of any bed in the section is unchanged" (Ramsay and Huber 1987, p.557). Such area restorations therefore presuppose no compaction or out of plane movement (see Fossen, 2016, p.444 for a summary) and as such are not suitable in the present gravity-driven FATS.

Koyi et al. (2004) and Nilforoushan et al. (2008) used loose sand in analogue models to examine the effects of layer compaction on both bed length and area balancing techniques. These 
authors show that lower friction decollements result in lower values of volume decrease and lateral compaction, whereas higher friction decollements are marked by greater amounts of volume loss. Although the detachments in the present study are considered to be low friction, the surficial nature of the deformation in uncompacted and water-saturated sediments still appears to encourage compaction to occur. Compaction will also clearly affect expulsion of fluids, which may then migrate upwards along footwall synforms and pond below thrusts thereby helping to drive further downslope movement and propagation of detachments (e.g. Alsop et al. 2018, 2021).

In summary, the thrust ramps we have described are developed on a small decametric scale in unlithified sediments where the effects of downward propagating thrusts can be accommodated by DVC. Conversely, in orogenic settings marked by much larger km-scale fold and thrust systems, vertical motion associated with shortening is clearly more likely to be accommodated by surficial uplift and consequent erosion. However, improved seismic analysis has led to an increasing recognition of large-scale gravity-driven fold and thrust systems operating in continental slopes that may be underlain by thick units of weak shale or salt (e.g. see review by Morley et al. 2017). These weaker horizons along which deformation is focussed are potentially able to accommodate vertical motion along downward-propagating thrust ramps by lateral flow, possibly leading to some of the issues with critical tapers and section balancing noted above.

\section{Conclusions}

In this case study, we have developed the original framework of Ramsay (1992) that involves two end-member models of thrust ramp development and a third intermediate scenario by establishing a range of diagnostic parameters and geometries summarised below and on Table 1 .

Model 1 represents 'classic' end-member overthrust ramps in which marker beds in the hangingwall are uplifted above regional elevations while the footwall remains undeformed (Fig. 11a). The largest displacement generally develops lower down the ramp and decreases upwards towards the more gently dipping segments of the ramp. Fault propagation folding is marked by hangingwall antiforms above the upwardly-propagating ramp that result in a relative thinning of the hangingwall sequence and ramp cut-offs leading to values of stretch $<1$.

Model 2 represents end-member underthrust ramps in which marker beds in the footwall are depressed below regional elevations while the hangingwall remains undeformed (Fig. 11b). The largest displacement generally develops higher up the ramp and decreases downwards towards the more steeply dipping parts of the ramp. Fault propagation folding creates footwall synforms below the downwards-propagating ramp that result in a relative thinning of the footwall sequence and ramp cut-offs leading to values of stretch $>1$.

Model 3 represents intermediate mixed thrust ramps in which both the hangingwall and footwall are uplifted and depressed above and below regional elevations respectively (Fig. 11c). The largest displacement generally develops in the central part of the ramp and decreases both upwards and downwards away from this point. Fault propagation folding creates both 
819 hangingwall antiforms above the upwardly-propagating sections of the ramp, and footwall

820 synforms below the ramp that thin both the overlying and underlying sequence and cut-offs by

821 up to $25 \%$ and lead to values of stretch marginally $>1$.

822 As our case study is concerned with surficial gravity-driven FATS developed around the 823 Dead Sea Basin, it clearly demonstrates that deep burial of the thrust system is not a prerequisite

824 for underthrusting. The footwall to ramps do not underthrust the hangingwall by actively moving 825 back up the regional slope, but rather are over-ridden by the downslope movement of the active 826 hangingwall leading to differential vertical compaction below the ramp. As underthrusting 827 accommodates thrust-related shortening by deflecting the footwalls to ramps downwards below 828 regional elevations, it fails to build significant topography at the sediment-water interface.

829 Marker beds and crests of structures in the hangingwall maintain the same elevation despite 830 variable displacement, with the subdued topography less likely to form critical tapers or collapse 831 as in dynamic wedge models.

Acknowledgements

834 RW was supported by the Israel Science Foundation (ISF grant No. 868/17). SM acknowledges 835 the Israel Science Foundation (ISF grant No. 1436/14) and the Ministry of National

836 Infrastructures, Energy and Water Resources (grant \#214-17-027). TL acknowledges the Israeli 837 government GSI DS project 40706. We thank Stephen Laubach for efficient editorial handling of 838 the manuscript together with Chris Morley, Hemin Koyi and an anonymous referee for detailed 839 and constructive comments that much improved the paper. 
Table 1. Summary table highlighting criteria used to distinguish overthrust model 1, underthrust model 2 and mixed model 3 scenarios of thrust ramping.

\begin{tabular}{|c|c|c|c|}
\hline Parameter & Overthrust Model 1 & Underthrust Model 2 & Mixed Wedge Model 3 \\
\hline $\begin{array}{l}\text { a) Elevation of } \\
\text { regional markers }\end{array}$ & $\begin{array}{l}\text { Markers remain at or } \\
\text { above regional elevations }\end{array}$ & $\begin{array}{l}\text { Markers remain at or below } \\
\text { regional elevations }\end{array}$ & $\begin{array}{l}\text { Markers above and } \\
\text { below regional elevations }\end{array}$ \\
\hline $\begin{array}{l}\text { b) Movement of } \\
\text { hangingwall and footwall } \\
\text { to thrust ramp }\end{array}$ & $\begin{array}{l}\text { Hangingwall is uplifted } \\
\text { and potentially cut by } \\
\text { roof detachment }\end{array}$ & $\begin{array}{l}\text { Footwall is depressed } \\
\text { and potentially cut by } \\
\text { floor detachment }\end{array}$ & $\begin{array}{l}\text { Hangingwall is uplifted } \\
\text { and footwall is depressed } \\
\text { leading to potential truncations }\end{array}$ \\
\hline $\begin{array}{l}\text { c) Displacement - } \\
\text { Distance patterns } \\
\text { along thrust ramps }\end{array}$ & $\begin{array}{l}\text { Greatest displacement } \\
\text { developed lower down thrust } \\
\text { ramp and decreases upwards }\end{array}$ & $\begin{array}{l}\text { Greatest displacement } \\
\text { developed higher up thrust } \\
\text { ramp and decreases downwards }\end{array}$ & $\begin{array}{l}\text { Greatest displacement } \\
\text { generally developed in central } \\
\text { part of thrust ramp }\end{array}$ \\
\hline $\begin{array}{l}\text { d) Thickness variation } \\
\text { across thrust ramps }\end{array}$ & $\begin{array}{l}\text { Hangingwall sequence } \\
\text { is relatively thickened }\end{array}$ & $\begin{array}{l}\text { Footwall sequence is } \\
\text { relatively thinned }\end{array}$ & $\begin{array}{l}\text { Hangingwall and footwall } \\
\text { sequence are both thinned }\end{array}$ \\
\hline $\begin{array}{l}\text { e) Values of Stretch } \\
\text { across thrust ramps }\end{array}$ & $\begin{array}{l}\text { Stretch }<1 \\
\text { Hangingwall cut-offs are } \\
\text { relatively thinned }\end{array}$ & $\begin{array}{l}\text { Stretch }>1 \\
\text { Hangingwall cut-offs are } \\
\text { relatively thickened }\end{array}$ & $\begin{array}{l}\text { Stretch }>1 \\
\text { Footwall cut-offs are } \\
\text { relatively thinned }\end{array}$ \\
\hline $\begin{array}{l}\text { f) Thickness - dip } \\
\text { patterns across } \\
\text { thrust ramps }\end{array}$ & $\begin{array}{l}\text { Gentle ramps }\left(<20^{\circ}\right) \text { display } \\
\text { greater thickening of } \\
\text { hangingwall and footwall }\end{array}$ & $\begin{array}{l}\text { Steeper ramps }\left(>30^{\circ}\right) \text { display } \\
\text { greater thinning of } \\
\text { hangingwall and footwall }\end{array}$ & $\begin{array}{l}\text { Gentle ramps }\left(<20^{\circ}\right) \text { display } \\
\text { significant } 25 \% \text { thinning of } \\
\text { hangingwall and footwall }\end{array}$ \\
\hline $\begin{array}{l}\text { g) Displacement - } \\
\text { Dip patterns } \\
\text { along thrust ramps }\end{array}$ & $\begin{array}{l}\text { Displacement reduces with } \\
\text { decreasing dips along thrust } \\
\text { ramp }\end{array}$ & $\begin{array}{l}\text { Displacement increases with } \\
\text { decreasing dips along thrust } \\
\text { ramp }\end{array}$ & $\begin{array}{l}\text { Displacement generally } \\
\text { increases with decreasing dips } \\
\text { along thrust ramp }\end{array}$ \\
\hline $\begin{array}{l}\text { h) Thrust-related } \\
\text { fold patterns }\end{array}$ & $\begin{array}{l}\text { Hangingwall antiforms } \\
\text { develop with limited } \\
\text { folding in footwall }\end{array}$ & $\begin{array}{l}\text { Footwall synforms } \\
\text { develop with limited } \\
\text { folding in hangingwall }\end{array}$ & $\begin{array}{l}\text { Hangingwall antiforms } \\
\text { and footwall synforms } \\
\text { both develop }\end{array}$ \\
\hline $\begin{array}{l}\text { i) Dip of bedding } \\
\text { adjacent to } \\
\text { thrust ramps }\end{array}$ & $\begin{array}{l}\text { Beds in hangingwall rotate } \\
\text { towards thrust ramp while } \\
\text { footwall maintains regional } \\
\text { dips }\end{array}$ & $\begin{array}{l}\text { Beds in footwall rotate towards } \\
\text { thrust ramp while hangingwall } \\
\text { maintains regional dips }\end{array}$ & $\begin{array}{l}\text { Beds in both footwall and } \\
\text { hangingwall rotate towards } \\
\text { parallelism with thrust ramps }\end{array}$ \\
\hline
\end{tabular}


Figure 1 Schematic cartoons showing marker stratigraphy and a chosen regional ( $R e$ ) (dashed line) that is later cut by a thrust ramp. In all of these models, thrust ramps do not directly propagate from an underlying basal detachment. a) Overthrust model 1 where a fault propagation fold forms in the hangingwall (Hw) that is locally uplifted above regional (Re). b) Example of a overthrust ramp in Carboniferous sandstones and shales from south Wales (redrawn and mirrored from Chapman and Williams (1984, their fig. 1). c) Photograph and d) associated line drawing of an overthrust ramp from the Lisan Formation at Masada, Dead Sea. e) Underthrust model 2 where a fault propagation fold forms in the footwall $(\mathrm{Fw})$ that is locally depressed below regional (Re). f) Example of an underthrust ramp in limestones and marls exposed in a quarry, $30 \mathrm{~km}$ WNW of Zurich, Switzerland (redrawn and mirrored from Ramsay (1992, his fig.4). g) Mixed wedge model 3 where fault propagation folds form in the hangingwall and footwall and are locally uplifted and depressed relative to regional (Re). h) Example of a mixed ramp in Upper Jurassic dolostones and shales exposed in Kimmeridge Bay, UK. (redrawn from Ramsay (1992, his fig.13). In all cases, overall movement is towards the right, while thrust half arrows provide sense of absolute displacement across the thrust ramps.

Figure 2 a) Tectonic plates in the Middle East. General tectonic map showing the location of the present Dead Sea Fault (DSF) which transfers the opening motion in the Red Sea to the Taurus-Zagros collision zone. Red box marks the study area in the Dead Sea Basin. b) Generalised map (based on Sneh and Weinberger 2014) showing the current Dead Sea including the position of the Miflat, Masada, Peratzim and Wadi Zin localities referred to in the text. The extent of the Lisan Formation outcrops are also shown, together with the general fold and thrust system directions of the MTD's around the basin.

Figure 3 a) Schematic cartoon showing how the uplift or depression of chosen horizons (e.g. top of brown marker bed) in the hangingwall $(\mathrm{Hw})$ and footwall $(\mathrm{Fw})$ of a thrust ramp are measured relative to a regional elevation (Re). The amount of displacement of the marker across the thrust ramp is recorded relative to distance measured from a reference point (R) to the hangingwall cut-off (see text for further explanation). Distances down ramps are normalised against the maximum distance measured down a particular ramp, while uplift or depression of markers is normalised against the maximum recorded uplift or depression of that marker compared to its regional elevation (Re). Displacement of markers across a thrust ramp is normalised against the maximum offset recorded by any marker across that particular thrust ramp. The normalised distance measured down the thrust ramp from the reference point $(\mathrm{R})$ is compared with the normalised uplift or depression of regional markers for b) Model 1 overthrusts, c) Model 2 underthrusts, d) Model 3 mixed thrusts. The normalised displacement of markers across a thrust ramp is also compared with the normalised uplift or depression of regional markers for e) Model 1 overthrusts, f) Model 2 underthrusts, g) Model 3 mixed thrusts. In all cases, the key to different symbols and the figures showing related structures is shown at the top of the page. Open symbols in b-g) represent footwall data while closed symbols represent hangingwall data.

884 Figure 4 Photographs (a, c, e, g) and associated line drawings (b, h) of overthrust ramps (Model 1) from the Peratzim area (see Fig. $2 \mathrm{~b}$ for location). $10 \mathrm{~cm}$ chequered rule for scale. Note how a consistent regional elevation ( $\mathrm{Re}$ ) of marker beds (dashed line) is maintained in the footwall of ramps, while fault propagation folds are better developed in the hangingwalls. The hangingwall (Hw) cut-off length and footwall (Fw) cut-off length of a representative unit are highlighted across the ramp. In the photographs, matching coloured squares (footwall) and circles (hangingwall) mark offset horizons across the thrust ramps, with displacement generally decreasing towards the upper reference point (' $R$ ' in yellow circle). Displacement-distance (D-D) graphs are plotted for each example (c-d), (e-f), (h-i) with hangingwall cutoff markers (coloured circles) defining a displacement profile drawn from the yellow reference point (R) at the right-hand origin. The left-hand axis of the graph shows how the angle of dip of the ramp varies with distance along the thrust measured from $(\mathrm{R})$. The trend lines on each graph are for guidance only. 
Figure 5 Photographs (a, d, f,) and associated line drawings (b, e, g,) of an underthrust ramp (Model 2) from the Miflat area (see Fig. $2 \mathrm{~b}$ for location). $10 \mathrm{~cm}$ chequered rule for scale. Note how a consistent regional elevation $(\mathrm{Re})$ of marker beds is maintained towards the top of the ramp (e.g. shaded orange marker), while fault propagation folds (FPF) are better developed lower down in the footwall of the ramp (d). Position of detailed photographs (d, f) and associated drawings (e, g) are shown on b). In a), matching coloured squares (footwall) and circles (hangingwall) mark offset horizons across the thrust ramps, with displacement generally increasing towards the upper reference point (yellow circle). c) Displacementdistance (D-D) graph plotted for ramp shown in b), with hangingwall cut-off markers (coloured circles) defining a displacement profile drawn from the yellow reference point $(\mathrm{R})$ at the right-hand origin. The left-hand axis of the graph shows how the angle of dip of the ramp varies with distance along the thrust measured from (R). The trend lines on each graph are for guidance only. Inset stereoplot in $b$ ) shows orientation of thrust ramp and inferred transport towards $050^{\circ}$.

Figure 6 Photographs (a, c, f, h,) and associated line drawings (b, d, g,) of underthrust ramps (Model 2) from Miflat ( $\mathrm{a}, \mathrm{c}$ ) and Wadi Zin (f, h) areas (see Fig. $2 \mathrm{~b}$ for location). $10 \mathrm{~cm}$ chequered rule for scale. Note how a consistent regional elevation (Re) of marker beds is maintained towards the top of the ramps (e.g. shaded blue marker in b) and shaded marker with two yellow bands in $\mathrm{g}$ ), while fault propagation folds (FPF) are better developed lower down in the footwall of the ramp (d, g). Position of detailed photographs (c, h) are shown on b) and g) respectively. In c, h), matching coloured squares (footwall) and circles (hangingwall) mark offset horizons across the thrust ramps, with displacement generally increasing towards the upper reference point (yellow circle). e, i) Displacement-distance (D-D) graphs plotted for ramps shown in $\mathrm{c}, \mathrm{h}$ ), with hangingwall cut-off markers (coloured circles) defining a displacement profile drawn from the yellow reference point (R) at the right-hand origin. The left-hand axis of the graph shows how the angle of dip of the ramps varies with distance along the thrust measured from $(\mathrm{R})$. The trend lines on each graph are for guidance only.

Figure 7 Photographs (a, c, e,) and associated line drawings (b,f) of mixed wedge ramps (Model 3) from the Miflat area (see Fig. $2 \mathrm{~b}$ for location). $10 \mathrm{~cm}$ chequered rule for scale. Note how a consistent regional elevation (Re) of marker beds is maintained towards the top of the ramp (e.g. shaded orange marker bed in b) and f). Position of detailed photograph (c) is shown on b). In a, e), matching coloured squares (footwall) and circles (hangingwall) mark offset horizons across the thrust ramps, with displacement generally increasing towards the upper reference point (yellow circle). d, g) Displacement-distance (D-D) graphs plotted for ramps shown in b) and f) respectively, with hangingwall cut-off markers (coloured circles) defining displacement profiles drawn from the yellow reference point (R) at the right-hand origin. The left-hand axis of each graph shows how the angle of dip of the ramp varies with distance along the thrust measured from (R). The trend lines on each graph are for guidance only.

Figure 8 a) Schematic cartoon showing how stratigraphic normal thicknesses, ramp thicknesses and cutoff thicknesses are measured around fault propagation folds in the hangingwall $(\mathrm{Hw})$ and footwall $(\mathrm{Fw})$ of a thrust ramp. b) \% change in hangingwall thickness compared to $\%$ change in footwall thickness. c) Ratio of hangingwall ramp thickness over hangingwall normal thickness compared to ratio of footwall ramp thickness over hangingwall ramp thickness. d) Hangingwall cut-off thickness compared to footwall cut-off thickness. Values of stretch (see text for definition) are compared with e) the ratio of hangingwall ramp and footwall ramp thickness, f) $\%$ change in hangingwall thickness, g) $\%$ change in footwall thickness, h) dip of the thrust ramp. The dip of the thrust ramp is also compared with i) \% change in hangingwall thickness, and j) \% change in footwall thickness. In all cases, the key to different symbols and the figures showing related structures is shown at the top of the page. Individual open symbols in b-g) represent mean points for the different data sets.

Figure 9 Photographs $(a, f$,$) and associated line drawings ( b, g)$ from the Miflat area (see Fig. $2 b$ for location) of an overthrust ramp (Model 1) labelled Thrust A, underthrust ramp (Model 2) labelled Thrust 
B, and mixed wedge ramp (Model 3) labelled Thrust C. Note how the shaded orange marker bed is uplifted to a higher level above Thrust A, whereas it is depressed to lower levels beneath Thrusts B and C. Position of detailed photograph (f) is shown on b). In a), matching coloured squares (footwall) and circles (hangingwall) mark offset horizons across the thrust ramps labelled A-C, with distance along the ramp measured from the upper reference point (yellow circle) in each case. Displacement-distance (D-D) graphs are plotted for c) Thrust A, d) Thrust B, e) Thrust C, with hangingwall cut-off markers (coloured circles) defining displacement profiles drawn from the yellow reference point (R) at the right-hand origin. The left-hand axis of each graph shows how the angle of dip of the ramp varies with distance along the thrust measured from (R). The trend lines on each graph are for guidance only.

Figure 10 Photograph (a) and associated line drawing (b) from the Miflat area (see Fig. 2b for location) showing thrust ramps bound by overlying and underlying detachments (in green). $10 \mathrm{~cm}$ chequered rule for scale. Position of detailed photograph (d) is shown on b) and highlights extensional faults (in blue) that form in the footwall of thrust ramps and potentially linked to loading created by overthrusting. c) Displacement-distance (D-D) graphs showing reduction in displacement up towards the upper reference point, and consistent with overthrusting (Model 1). Photograph (e) and associated line drawing (f) from the Miflat area (see Fig. $2 \mathrm{~b}$ for location) showing a backthrust ramp bound by overlying and underlying detachments (in green). $15 \mathrm{~mm}$ diameter coin for scale. Note how a consistent level of marker beds is maintained towards the top of the ramp (e.g. shaded orange marker), while fault propagation folds (FPF) are better developed lower down in the footwall of the backthrust ramp (f). In e), matching coloured squares (footwall) and circles (hangingwall) mark offset horizons across the backthrust ramp, with displacement generally decreasing both upwards and downwards away from the orange marker horizon. g) Displacement-distance (D-D) graph plotted for the backthrust ramp shown in e), with hangingwall cutoff markers (coloured circles) defining displacement profiles drawn from the yellow reference point (R) at the right-hand origin. The left-hand axis of each graph shows how the angle of dip of the ramp varies with distance along the thrust measured from (R) to form a series of steps. The trend lines on each graph are for guidance only and show that larger displacement correlates with more gentle ramp dips.

Figure 11 Summary cartoons for a) Overthrust Model, b) Underthrust Model and c) Mixed Wedge Model. In each case, a series of evolutionary stages labelled i) to iii) show how ramps develop during continued movement, before being potentially truncated by overlying and underlying bedding-parallel detachments (in green). In a), the overthrust model leads to fault propagation folding in the hangingwall that is locally uplifted above regional elevation (Re), whereas in $b$ ) the underthrust model leads to fault propagation folding in the footwall that is locally depressed below regional. In c), the mixed wedge model creates fault propagation folds in both the hangingwall and footwall and are locally uplifted and depressed relative to regional. In b) and c) depression of the footwall is achieved through differential vertical compaction (DVC) of weak underlying sediments, with the position of footwall synforms remaining fixed and simply being over-ridden by downslope movement of the hangingwall (towards the right). Thrust half arrows provide sense of absolute displacement across the thrust ramps.

\section{References}

Agnon, A., Migowski, C., Marco, S., 2006. Intraclast breccia layers in laminated sequences: recorders of paleo-earthquakes, in Enzel, Y., Agnon, A., and Stein, M., eds., New Frontiers in Dead Sea Paleoenvironmental Research, Geological Society of America Special Publication, p. 195-214.

Alsop, G.I., Marco, S., Levi, T., Weinberger, R. 2017a. Fold and thrust systems in Mass Transport Deposits. Journal of Structural Geology 94, 98-115.

Alsop, G.I., Marco, S., Weinberger, R., Levi, T. 2017b. Upslope-verging back thrusts developed during downslope-directed slumping of mass transport deposits. Journal of Structural Geology 100, 45-61.

Alsop, G.I., Weinberger, R., Marco, S. 2018. Distinguishing thrust sequences in gravity-driven fold and thrust belts. Journal of Structural Geology 109, 99-119. 
990

991

992

993

994

995

996

997

998

999

1000

1001

1002

1003

1004

1005

1006

1007

1008

1009

1010

1011

1012

1013

1014

1015

1016

1017

1018

1019

1020

1021

1022

1023

1024

1025

1026

1027

1028

1029

1030

Alsop, G.I., Weinberger, R., Marco, S., Levi, T. 2019. Identifying soft-sediment deformation in rocks. Journal of Structural Geology 125, 248-255. doi.org/10.1016/j.jsg.2017.09.001

Alsop, G.I., Weinberger, R., 2020. Are slump folds reliable indicators of downslope flow in recent mass transport deposits? Journal of Structural Geology 135, 104037. https://doi.org/10.1016/j.jsg.2020.104037

Alsop, G.I., Weinberger, R., Marco, S., Levi, T. 2020a. Fold and thrust systems in mass transport deposits around the Dead Sea Basin. In: Ogata, K., Festa, A., Pini, G.A. (Editors). Submarine landslides: subaqueous mass transport deposits from outcrops to seismic profiles. American Geophysical Union Monograph Series. 246, p.139-154. John Wiley \& Sons Inc. 384pp. ISBN: 978-1-119-50058-2.

Alsop, G.I., Weinberger, R., Marco, S., Levi, T. 2020b. Bed-parallel slip: Identifying missing displacement in mass transport deposits. Journal of Structural Geology 131, 103952.

Alsop, G.I., Weinberger, R., Marco, S., Levi, T. 2020c. Distinguishing coeval patterns of contraction and collapse around flow lobes in mass transport deposits. Journal of Structural Geology 134, 104013

Alsop, G.I., Weinberger, R., Marco, S., Levi, T. 2020d. Folding during soft-sediment deformation. Geological Society Special Publication, Bond, C.E. and Lebit, H.D. (Editors) Folding and fracturing of rocks: 50 years since the seminal text book of J.G. Ramsay. 487, 81-104. doi.org/10.1144/SP487.1

Alsop, G.I., Weinberger, R., Marco, S., Levi, T. 2021. Detachment fold duplexes within gravity-driven fold and thrust systems. Journal of Structural Geology, 142, 104207. https://doi.org/10.1016/j.jsg.2020.104207

Armandita, C., Morley, C.K., Rowell, P. 2015. Origin, structural geometry, and the development of a giant slide: The South Makassar Strait mass transport complex. Geosphere, 11, 376-403.

Bartov, Y., Steinitz, G., Eyal, M., Eyal, Y., 1980. Sinistral movement along the Gulf of Aqaba - its age and relation to the opening of the Red Sea: Nature 285, 220-221.

Bartov, Y., Stein, M., Enzel, Y., Agnon, A., Reches, Z., 2002. Lake levels and sequence stratigraphy of Lake Lisan, the late Pleistocene precursor of the Dead Sea. Quaternary Research 57, 9-21.

Bartov, Y., Goldstein, S.L., Stein, M., Enzel, Y. 2003. Catastrophic arid episodes in the Eastern Mediterranean linked with the North Atlantic Heinrich events. Geology 31, 439-442.

Begin, Z.B., Ehrlich, A., Nathan, Y., 1974. Lake Lisan, the Pleistocene precursor of the Dead Sea: Geological Survey of Israel Bulletin, 63, p. 30.

Begin, B.Z., Steinberg, D.M., Ichinose, G.A., and Marco, S., 2005. A 40,000 years unchanging of the seismic regime in the Dead Sea rift: Geology, v. 33, p. 257-260.

Ben-Dor, Y., Neugebauer, I., Enzel, Y., Schwab, M.J., Tjallingii, R., Erel, Y., Brauer, A. 2019. Varves of the Dead Sea sedimentary record. Quaternary Science Reviews 215, 173-184.

Berlenbach, J.W. 1995. Underthrusting in the Kloof Gold Mine. South African Journal of Geology 98, 3542.

Boyer, S.E., Elliot, D. 1982. Thrust systems. American Association of Petroleum Geologists Bulletin 66, 1196-1230.

Boyer, S.E. 1992. Geometric evidence for synchronous thrusting in the southern Alberta and northwest Montana thrust belts. In: McClay, K. (Editor), Thrust Tectonics. Chapman and Hall. London. p. 377-390.

Butler, R.W.H., 1987. Thrust sequences. Journal of the Geological Society, London, 144, 619-634.

Butler, R.W.H., Paton, D.A. 2010. Evaluating lateral compaction in deepwater fold and thrust belts: How much are we missing from "nature's sandbox"? GSA Today 20, 4-10. 
Butler, R.W.H., Bond, C.E., Cooper, M.A., Watkins, H. 2020. Fold-thrust structures - where have all the buckles gone? Geological Society Special Publication, Bond, C.E. and Lebit, H.D. (Editors) Folding and fracturing of rocks: 50 years since the seminal text book of J.G. Ramsay. 487, 21-44.

Cardona, S., Wood, L.J., Dugan, B., Jobe, Z., Strachan, L.J. 2020. Characterization of the Rapanui masstransport deposit and the basal shear zone: Mount Messenger Formation, Taranaki Basin, New Zealand. Sedimentology, 67, 2111-2148, https://doi.org/10.1111/sed.12697

Cawood, A.J., Bond, C.E. 2020. Broadhaven revisited: a new look at models of fault-fold Interaction. In: Bond, C.E., Lebit, H.D. (Editors) Folding and Fracturing of Rocks: 50 Years of Research since the Seminal Text Book of J. G. Ramsay. Geological Society, London, Special Publications, 487, 105-126.

Chapman, T.J., Williams, G.D. 1984. Displacement-distance methods in the analysis of fold-thrust structures and linked-fault systems. Journal of the Geological Society 141, 121-128.

Chester, J., Chester, F. 1990. Fault propagation folds above thrusts with constant dip. Journal of Structural Geology 12, 903-910.

Cloos, E. 1961. Bedding slips, wedges and folding in layered sequences. Bulletin de la Commission Géologique de Finlande 33, 106-122.

Cloos, E. 1964. Wedging, bedding plane slips, and gravity tectonics in the Appalachians. Memoirs of the Department of Geological Sciences, Virginia Polytechnic Institute 1, 63-70.

Cooper, M. A., Garton, M.R., Hossack, J.R. 1983. The origin of the Basse Normandie duplex, Boulonnais, France. Journal of Structural Geology 5, 139-152.

Cooper, M.A., Trayner, P,M. 1986. Thrust-surface geometry: implications for thrust belt-evolution and section-balancing techniques. Journal of Structural Geology 8, 305-312.

Dahlen, F.A. 1990. Critical taper model of fold- and thrust- belts and accretionary wedges. Annual Reviews Earth Planetary Science 18, 55-99.

Davis, D., Suppe, J., Dahlen, F.A. 1983. Mechanics of fold-and-thrust belts and accretionary wedges. Journal of Geophysical Research 88, (B2), 1153-1172.

Davis, D.M., and Engelder, T., 1985, The role of salt in fold-and-thrust belts: Tectonophysics, 119, p. 67-88.

Eisenstadt, G., De Paor, D.G. 1987. Alternative model of thrust-fault propagation. Geology 15, 630-633.

El-Isa, Z.H., Mustafa, H. 1986. Earthquake deformations in the Lisan deposits and seismotectonic implications. Geophysical Journal of the Royal Astronomical Society 86, 413-424.

Ellis, M.A., Dunlap, W.J. 1988. Displacement variation along thrust faults: implications for the development of large faults. Journal of Structural Geology 10, 183-192.

Ferrill, D.A., 1988. Use of fault cut-offs and bed travel distance in balanced cross-sections:

Discussion 2. Journal of Structural Geology 10, 313-314.

Ferrill, D.A., Morris, A.P., Wigginton, S.S., Smart, K.J., McGinnis, R.N., Lehrmann, D. 2016. Deciphering thrust fault nucleation and propagation and the importance of footwall synclines. Journal of Structural Geology, 85, 1-11.

Fischer, M.P., Woodward, N.B., Mitchell, M.M. 1992. The kinematics of break-thrust folds. Journal of Structural Geology, 14, 451-460.

Fossen, H. 2016. Structural Geology. $2^{\text {nd }}$ Edition. Cambridge University Press, Cambridge, UK, p.510.

Frey Martinez, J., Cartwright, J., Hall, B. 2005. 3D seismic interpretation of slump complexes: examples from the continental margin of Israel. Basin Research 17, 83-108. 
Frey-Martinez, J., Cartwright, J., James, D. 2006. Frontally confined versus frontally emergent submarine landslides: A 3D seismic characterisation. Marine and Petroleum Geology23, 585-604.

Garfunkel, Z., 1981. Internal structure of the Dead Sea leaky transform (rift) in relation to plate kinematics: Tectonophysics 80 , p. 81-108.

Haase-Schramm, A., Goldstein, S.L., Stein, M. 2004. U-Th dating of Lake Lisan aragonite (late Pleistocene Dead Sea) and implications for glacial East Mediterranean climate change. Geochimica et Cosmochimica Acta 68, 985-1005.

Haliva-Cohen, A., Stein, M., Goldstein, S.L., Sandler, A., Starinsky, A. 2012. Sources and transport routes of fine detritus material to the Late Quaternary Dead Sea Basin. Quaternary Science Reviews 50, 55-70.

Hedlund, C.A. 1997. Fault-propagation, ductile strain, and displacement-distance relationships. Journal of Structural Geology 19, 249-256.

Hossack, J.R. 1979. The use of balanced cross sections in the calculation of orogenic contraction. Journal of the Geological Society of London, 136, 705-711.

Hughes, A.N., Shaw, J.H. 2014. Fault displacement-distance relationships as indicators of contractional fault-related folding style. American Association of Petroleum Geologists Bulletin 98, 227-251.

Jablonska, D., Di Celma, C., Tondi, E., Alsop, G.I. 2018. Internal architecture of mass-transport deposits in basinal carbonates: A case study from southern Italy. Sedimentology 65 (4), 1246-1276. doi: $10.1111 /$ sed. 12420

Kagan, E.J., Stein, M., Marco, S. 2018. Integrated palaeoseismic chronology of the last glacial Lake Lisan: From lake margin seismites to deep-lake mass transport deposits. Journal of Geophysical Research: Solid Earth 123 (4) 2806-2824.

Ken-Tor, R., Agnon, A., Enzel, Y., Marco, S., Negendank, J.F.W., and Stein, M., 2001. High-resolution geological record of historic earthquakes in the Dead Sea basin: J. Geophys. Res., v. 106, p. 2221-2234.

Kim, Y.S., Sanderson, D.J. 2005. The relationship between displacement and length of faults. Earth Science Reviews 68, 317-334.

Knipe, R.J. 1985. Footwall geometry and the rheology of thrust sheets. Journal of Structural Geology 7, 1-10.

Koyi, H. 1995. Mode of internal deformation in sand wedges. Journal of Structural Geology 17, 293-300.

Koyi, H.A., Sans, M., Teixell, A., Cotton, J., Zeyen, H. 2004. The significance of penetrative strain in the restoration of shortened layers - insights from sand models and the Spanish Pyrenees. In: McClay, K.R. (Editor) Thrust Tectonics and hydrocarbon systems. American Association of Petroleum Geology Memoir 82, 207-222.

Koyi, H.A., Maillot, B. 2007. Tectonic thickening of hanging-wall units over a ramp. Journal of Structural Geology 29, 924-932.

Levi, T., Weinberger, R., Aïfa, T., Eyal, Y., S. Marco, S. 2006a. Injection mechanism of clay-rich sediments into dikes during earthquakes, Geochemistry, Geophysics, and Geosystems 7, no. 12, Q12009.

Levi, T., Weinberger, R., Aïfa, T., Eyal, Y., S. Marco, S. 2006b. Earthquake-induced clastic dikes detected by anisotropy of magnetic susceptibility, Geology, 34(2), 69-72.

Levi, T., Weinberger, R., Alsop, G.I., Marco, S. 2018. Characterizing seismites with anisotropy of magnetic susceptibility. Geology 46 (9), 827-830.

Lu, Y., Waldmann, N., Alsop, G.I., Marco, S. 2017. Interpreting soft sediment deformation and mass transport deposits as seismites in the Dead Sea depocentre. Journal of Geophysical Research: Solid Earth, 122. $10,8305-8325$. 
1114

1115

1116

1117

1118

1119

1120

1121

1122

1123

1124

1125

1126

1127

1128

1129

1130

1131

1132

1133

1134

1135

1136

1137

1138

1139

1140

1141

1142

1143

1144

1145

1146

1147

1148

1149

1150

1151

1152

1153

1154

1155

1156

Lu, Y., Moernaut, J., Bookman, R., Waldmann, N., Wetzler, N., Agnon, A., Marco, S., Alsop, G.I., Strasser, M., Hubert-Ferrari, A. 2021. A new approach to constrain the seismic origin for prehistoric turbidites as applied to the Dead Sea Basin. Geophysical Research Letters, 48, e2020GL090947. http://doi.org/10.1029/2020GL090947

Marco, S., Stein, M., Agnon, A., and Ron, H., 1996. Long term earthquake clustering: a 50,000 year paleoseismic record in the Dead Sea Graben: J. Geophys. Res., 101, 6179-6192.

Marco, S., Hartal, M., Hazan, N., Lev, L., Stein, M. 2003. Archaeology, history, and geology of the A.D. 749 earthquake, Dead Sea transform. Geology 31, 665-668.

Martinez-Torres, L.M., Ramon-Lluch, R., Eguiluz, L. 1994. Tectonic wedges: geometry and tectonic interpretation. Journal of Structural Geology 16, 1491-1494.

McClay, K.R., 1992. Glossary of thrust tectonic terms. In: McClay, K.R. (Editor) Thrust Tectonics. Chapman and Hall, London. P. 419-433.

McConnel, D.A., Kattenhorn, S.A., Benner, L., 1997. Distribution of fault slip in outcrop-scale fault-related folds, Appalachian mountains. Journal of Structural Geology 19, 257-267.

McNaught, M.A., Mitra, G., 1993. A kinematic model for the origin of footwall synclines. Journal of Structural Geology 15, 805-808.

Migowski, C., Agnon, A., Bookman, R., Negendank, J.F.W., and Stein, M., 2004, Recurrence pattern of Holocene earthquakes along the Dead Sea transform revealed by varve-counting and radiocarbon dating of lacustrine sediments: Earth and Planetary Science Letters, v. 222, p. 301-314.

Mitra, S. 1992. Balanced structural interpretation in fold and thrust belts. In: Mitra, S., Fisher, G.W. (Editors), Structural geology of fold and thrust belts. The Johns Hopkins University Press. Baltimore and London. p. 53-77. pp.254.

Morley, C.K., 1986. Vertical strain variations in the Osen-Røa thrust sheet, North-western Oslo Fjord, Norway. Journal of Structural Geology 8, 621-632.

Morley, C.K., 1994. Fold-generated imbricates: examples from the Caledonides of Southern Norway. Journal of Structural Geology 16, 619-631.

Morley, C.K., King, R., Hillis, R., Tingay, M., Backe, G. 2011. Deepwater fold and thrust belt classification, tectonics, structure and hydrocarbon prospectivity: A review. Earth Science Reviews, 104, 41-91.

Morley, C.K., von Hagke, C., Hansberry, R.L., Collins, A.S., Kanitpanyacharoen, W., King, R. 2017. Review of major shale-dominated detachment and thrust characteristics in the diagenetic zone: Part 1, mesoand macro-scopic scale. Earth Science Reviews173, 168-228.

Morley, C.K., Jitmahantakul, S., von Hagke, C., Warren, J., and Linares, F., 2021, Development of an intra-carbonate detachment during thrusting: The variable influence of pressure solution on deformation style, Khao Khwang Fold and Thrust Belt, Thailand: Geosphere, 17, p. 602-625, https:// doi .org /10.1130/GES02267.1.

Muraoka, H., Kamata, H., 1983. Displacement distribution along minor fault traces. Journal of Structural Geology 5, 483-495.

Nilforoushan, F., Koyi, H.A., Swantesson, J.O.H., Talbot, C.J. 2008. Effect of basal friction on surface and volumetric strain in models of convergent settings measured by laser scanner. Journal of Structural Geology $30,377-379$.

Noble, T.E., Dixon, J.M., 2011. Structural evolution of fold-thrust structures in analog models deformed in a large geotechnical centrifuge. Journal of Structural Geology 33, 62-77. 
Nugraha, H.D., Jackson, C, A-L., Johnson, H.D., Hodgson, D.M. 2020. Lateral variability in strain along the toewall of a mass transport deposit: a case study from the Makassar Strait, offshore Indonesia. Journal of the Geological Society 177, 1261-1279. https://doi.org/10.1144/jgs2020-071

Nuriel,P., Weinberger, R., Kylander-Clark, A.R.C., Hacker, B.R., Cradock, J.P. 2017. The onset of the Dead Sea transform based on calcite age-strain analyses. Geology 45, 587-590.

Peacock, D.C.P., Sanderson, D.J. 1996. Effects of propagation rate on displacement variations along faults. Journal of Structural Geology 18, 311-320.

Prasad, S., Negendank, J.F.W., Stein, M. 2009. Varve counting reveals high resolution radiocarbon reservoir age variations in palaeolake Lisan. Journal of Quaternary Science 24, 690-696.

Price, N.J., Cosgrove, J.W. 1990. Analysis of Geological Structures. Cambridge University Press. 502pp.

Ramsay, J.G. 1967. Folding and fracturing of rocks. McGraw-Hill. New York. pp.568.

Ramsay, J.G., Huber, M.I. 1987. The techniques of modern structural geology. Volume 2. Academic Press, London. 309-700pp.

Ramsay, J. G. 1992. Some geometric problems of ramp-flat thrust models. In K. R. McClay (Ed.), Thrust tectonics pp 191-201. London UK: Chapman and Hall.

Rosas, F.M., Duarte, J.C., Almeida, P., Schellart, W.P., Riel, N., Terrinha, P. 2017. Analogue modelling of thrust systems: Passive vs. active hanging wall strain accommodation and sharp vs. smooth fault-ramp geometries. Journal of Structural Geology 99, 45-69.

Sammartini, M., Moernaut, J., Kopf, A., Stegmann, S., Fabbri, S.C., Anselmetti, F.S., Strasser, M. 2021. Propagation of frontally confined subaqueous landslides: Insights from combining geophysical, sedimentological, and geotechnical analysis, Sedimentary Geology, https://doi.org/10.1016/j.sedgeo.2021.105877

Scarselli, N., McClay, K., Elders, C. 2016. Seismic geomorphology of Cretaceous megaslides offshore Namibia (Orange Basin): Insights into segmentation and degradation of gravity-driven linked systems. Marine and Petroleum Geology 75, 151-180.

Sharman, G.R., Graham, S.A., Masalimova, L.U., Shumaker, L.E., King, P.R. 2015. Spatial patterns of deformation and palaeoslope estimation within the marginal and central portions of a basin-floor mass-transport deposit, Taranaki Basin, New Zealand. Geosphere, 11, 266-306.

Sneh, A., Weinberger, R. 2014. Major structures of Israel and Environs, Scale 1:500,000. Israel Geological Survey, Jerusalem.

Sobiesiak, M., Kneller, B.C., Alsop, G.I., Milana, J.P. 2016. Internal deformation and kinematic indicators within a tripartite Mass Transport Deposit, NW Argentina. Sedimentary Geology 344, $364-381$.

Sobiesiak, M., Kneller, B.C., Alsop, G.I., Milana, J.P. 2017. Sub-seismic scale folding and thrusting within an exposed mass transport deposit: A case study from NW Argentina. Journal of Structural Geology 96, 176-191.

Sobiesiak, M., Kneller, B.C., Alsop, G.I., Milana, J.P. 2018. Styles of basal interaction beneath mass transport deposits. Marine and Petroleum Geology 98, 629-639.

Steventon, M.J., Jackson, C,A-L, Hodgson, D.M., Johnson, H.D. 2019. Strain analysis of a seismically imaged mass-transport complex, offshore Uruguay. Basin Research 31, 600-620.

Strayer, L.M., Hudleston, P.J. 1997. Numerical modelling of fold initiation at thrust ramps. Journal of Structural Geology 19, 551-566.

Suppe, J. 1983. Geometry and kinematics of fault-bend folding. American Journal of Science 283, 684-721. 
Suppe, J., Medwedeff, D.A. 1984. Fault propagation folding. Geological Society of America Abstracts with programs 16, 670 .

Suppe, J., Medwedeff, D.A. 1990. Geometry and kinematics of fault-propagation folding. Eclogae geol. Helv. 83/3 409-454.

Tavani, S., Storti, F., Salvini, F. 2006. Double-edge propagation folding: geometry and kinematics. Journal of Structural Geology 28, 19-35.

Thorbjornsen, K.L., Dunne, W.M., 1997. Origin of a thrust-related fold: geometric vs kinematic tests. J. Struct. Geol. 19, 303-319.

\section{Twiss, R.J., Moores, E.M. 2007. Structural geology. $2^{\text {nd }}$ edition. W.H. Freeman and Company. New} York. 736pp.

Weinberger, R., Levi, T., Alsop, G.I., Eyal, Y. 2016. Coseismic horizontal slip revealed by sheared clastic dikes in the Dead Sea basin. Geological Society of America Bulletin 128, 1193-1206.

Weinberger, R., Levi, T., Alsop, G.I., Marco, S. 2017. Kinematics of Mass Transport Deposits revealed by magnetic fabrics. Geophysical Research Letters 44, 7743-7749.

Williams, G., Chapman, T. 1983. Strains developed in the hangingwall of thrusts due to their slip/propagation rate: a dislocation model. Journal of Structural Geology 5, 563-571.

Woodward, N.B., 1987. Geological applicability of critical-wedge thrust-belt models. Geological Society of America Bulletin, 99, 827-832.

Woodward, N.B. 1992. Deformation styles and geometric evolution of some Idaho-Wyoming thrust belt structures. In: Mitra, S., Fisher, G.W. (Editors), Structural geology of fold and thrust belts. The Johns Hopkins University Press. Baltimore and London. p. 191-206. pp.254.

Uzkeda, H., Poblet, J., Bulnes, M. 2010. A geometric and kinematic model for double-edge propagating thrusts involving hangingwall and footwall folding. An example from the Jaca-Pamplona Basin (Southern Pyrenees). Geological Journal, 45, 506-520. 